\title{
AGRICULTURA FAMILIAR: RECUPERAÇÃO E VALORAÇÃO DA FLORESTA NO ASSENTAMENTO RURAL DE SUMARÉ II (SP)
}

\section{LOIDE DE OLIVEIRA PONTES}

Bacharel em Ciências Sociais

Orientador: Prof. Dr. DALCIO CARON

Dissertação apresentada à Escola Superior de Agricultura "Luiz de Queiroz", Universidade de São Paulo, para obtenção do título de Mestre em Recursos Florestais, com opção em Conservação de Ecossistemas Florestais.

P I R A C I C A B A

Estado de São Paulo - Brasil

Agosto - 2003 


\section{ERRATA}

- Página 40, Linha 8: onde lê-se "serve aos dois assentamentos sem grandes problemas." leia-se "é feito normalmente.".

- Página 56, Linha 4. onde lê-se 2, leia-se 3.

- Página 56, Linha 5. onde lê-se 18,5 leia-se 17,5.

- Página 56, Linha 6. onde lê-se "para os juíres 2, 3 e 4" leia-se "para o juiz 4".

- Página 59, Linha 11: onde lê-se "faixa vermelha" leia-se "faixa verde".

- Inclusão nas Referências Bibliográficas:

FEDERAÇÃO DA AGRICULTURA DO ESTADO DE SÃO PAULO - FAESP. Informe Econômico, São Paulo, n.51, p.1-8, maio 2002. http://www.faespsenar.com.br/faespi economico/Informativo\%20economico/2002/maio02.pdf (29 ago.2003). 


\section{Dados Internacionais de Catalogação na Publicação (CIP) DIVISĀO DE BIBLIOTECA E DOCUMENTAÇÃO - ESALQ/USP}

\section{Pontes, Loide de Oliveira}

Agricultura familiar: recuperação e valoração da floresta no assentamento rural de Sumaré Il (SP) / Loide de Oliveira Pontes. - Piracicaba, 2003.

$90 \mathrm{p}$. 2003.

Dissertação (mestrado) - Escola Superior de Agricultura Luiz de Queiroz, Bibliografia.

1. Agricultura familiar 2. Assentamento rural 3. Ecologia humana 4. Florestas 5. Meio ambiente - Recuperação I. Titulo

CDD 630 
A você, Cida (in memoriam), que semeou seus sonhos em cada área reflorestada dentro do assentamento. 


\section{AGRADECIMENTOS}

Aos moradores do Sumaré II e ao Reginaldo, técnico do ITESP, que contribuíram com valiosas informações, sem as quais não teria sido possível a elaboração deste trabalho.

Aos professores e funcionários dos Departamentos de Ciências Florestais da ESALQ/USP pela colaboração nos momentos importantes desta caminhada.

Aos professores. Eneida Elisa Mello da Costa (ESALQ), Sergius Gandolf (ESALQ), Antonio Natal Gonçalves (ESALQ), Flávio Bertin (ESALQ), Sônia Bergamasco (UNICAMP), Kely Junqueira (UNICAMP), e Julieta Teresa (UNICAMP) exemplos de humanidade, educadores autênticos e amigos.

Ao Prof. Dr. Dalcio Caron, meu orientador, cuja paciência, cooperação e apoio foram fundamentais para a realização deste trabalho.

Ao meu pai e à minha mãe (in memoriam) e a Cármina (minha sogra) aos meus filhos, Júnior, Eduardo e Ana Carolina eu ofereço.

Especialmente ao meu esposo, Antonio Carlos, que com seu apoio carinhoso me incentivou e me acompanhou em cada passo deste trabalho com sugestões valiosas. 


\section{SUMÁRIO}

Página

LISTA DE FIGURAS …........................................................................... viii

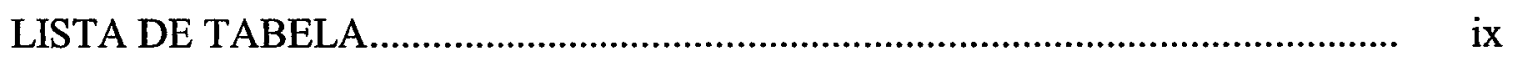

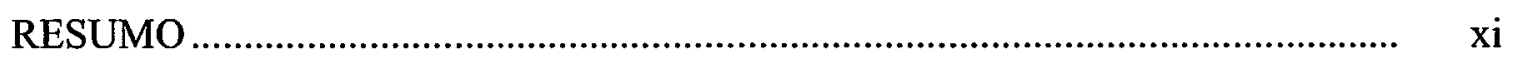

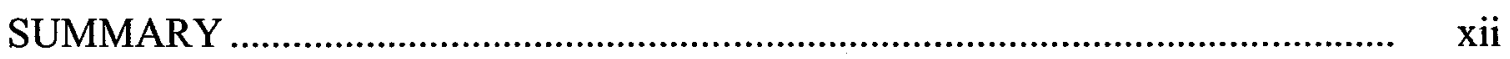

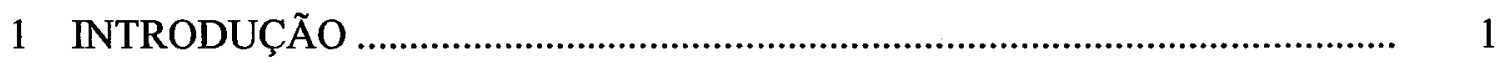

1.1 Considerações Gerais................................................................................ 1

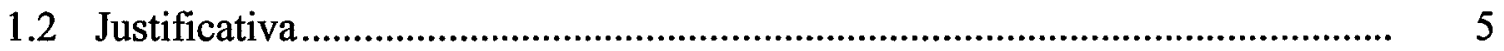

2 REVISÃO BIBLIOGRÁFICA ..................................................................... 9

2.1 O homem e sua relação com a natureza............................................................ 9

2.2 Agricultura: repensando o meio ambiente ……...................................................... 19

2.2.1 Breve histórico da evolução da agricultura....................................................... 19

2.2.2.1 Conceitos teóricos: o pensamento humano e representação social - elementos para compreensão da ação do homem no meio ambiente ................................ 23

3 ASSENTAMENTO E MEIO AMBIENTE: O CASO DO SUMARÉ II .......... 31

3.1 Caracterização da área do estudo ................................................................... 31

3.2 Definição do método e técnicas ..................................................................... 31

3.3 Fonte dos Dados ................................................................................. 38

$4 \quad$ RESULTADOS E DISCUSSÕES ............................................................... 39

4.1 Perfil do produtor familiar do Sumaré II ........................................................ 39

4.1.1 Perfil social do produtor familiar...................................................................... 39 
4.1.2 Perfil econômico do produtor familiar ................................................................. 46

4.2 Relação com a natureza ..................................................................................... 50

4.2.1 Sistemas AgroFlorestais como prática alternativa da atividade agrícola.......... 50

4.2.2 Função protetora da mata ciliar do Sumaré II..................................................... 51

4.3 Representação ecológica do produtor familiar do Sumaré II............................ 53

4.3.1 Criação do IREc ( Índice de Representação Ecológica) ....................................... 53

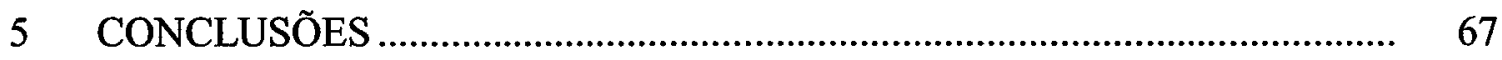

REFERÊNCIAS BIBLIOGRÁFICAS _......................................................... 74

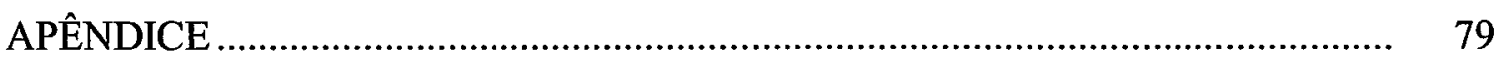




\section{LISTA DE FIGURAS}

Página

1 Plantação semi-orgânica.......................................................................................... 48

2 Produtos orgânicos: definição ................................................................................ 49

3 Dendrograma: similaridade entre os juízes ......................................................... 55

4 Dendrograma: similaridade entre as famílias....................................................... 60

5 Famílias por ordem crescente do IREc e grupos formados ..................................... 62

6 Nuvem de pontos e reta de regressão ajustada ....................................................... 64 


\section{LISTA DE TABELAS}

Página

1 Limites inferiores e superiores dos grupos ...................................................... 38

2 Número de cômodos ........................................................................................... 40

3 Número de casas por lote................................................................................. 41

4 Idade da população do assentamento Sumaré II .................................................... 41

5 Faixa etária por sexo da população do Assentamento Sumaré II........................... 42

6 Estado civil da população do assentamento Sumaré II........................................... 42

7 Distribuição do estado civil da população por faixa etária ..................................... 43

8 Relação de parentesco com o responsável pelo lote ................................................. 43

9 Religião declarada............................................................................................... 44

10 Situação atual em relação à situação antes de vir para o assentamento ................ 44

11 Cidade onde residia o titular antes de vir para o assentamento ............................ 44

12 Tempo que a família reside no assentamento ....................................................... 45

13 Atividade anterior do titular antes de residir no assentamento ........................... 45

14 Valor obtido pela venda da produção e percentual em relação ao total anual .... 47

15 Respostas relativas à implantação do Safs........................................................... 51

16 Passos de construção dos agrupamentos - semelhança entre os juízes ................ 55

17 Média e classificação dada pelos juizes, feita de forma separada......................... 56

18 IREc e classificação através deste índice ............................................................... 57

19 Limites inferiores e superiores dos grupos ............................................................. 58

20 Pontos de corte para o IREc, considerando a divisão em três grupos.................. 59

21 Análise de agrupamentos hierárquica das observações utilizando distância 
Euclidiana e ligação de Ward............................................................................ 61

22 Quadro de análise de regressão ...................................................................... 64

23 Médias, medianas, valores mínimos e máximos do IREc para cada grupo de graus de instrução do titular................................................................................................ 65

24 Médias, medianas, valores mínimos e máximos do IREc para cada grupo de graus de instrução média dos moradores em idade escolar .................................................. 65 


\title{
AGRICULTURA FAMILIAR: RECUPERAÇÃO E VALORAÇÃO DA FLORESTA NO ASSENTAMENTO RURAL DE SUMARÉ II (SP)
}

\author{
Autora: LOIDE DE OLIVEIRA PONTES \\ Orientador: Prof. DALCIO CARON
}

\section{RESUMO}

Os produtores familiares do Assentamento rural de Sumaré II - S.P. foram objeto de estudo deste trabalho. Buscou-se traçar os perfis social e econômico como também, através do Índice proposto (Índice de Representação Ecológica - IREc), analisar o grau de importância do meio ambiente na atividade do produtor familiar. As análises tomam, como referência básica, a pesquisa de campo, centrada em variáveis obtidas através de um questionário aplicado no local, em conjunto com a observação centrando-se em atos ocorridos na agricultura que contribuem para a degradação ambiental. A aplicação do índice permitiu ao pesquisador melhor compreensão da realidade estudada. Além disto os resultados poderão auxiliar na orientação de ações que poderão intervir para transição do modelo de agricultura convencional para estilos de agricultura de base ecológica. A utilização do IREc tende a facilitar a identificação de agentes locais de sustentabilidade, que poderão dar continuidade as mudanças em direção a estágios mais avançados de sustentabilidade econômica, social e ambiental. 


\title{
FAMILIAR AGRICULTURE: FOREST'S RECUPERATION AND VALUATION IN SUMARÉ II'S RURAL ESTABLISHMENT (SP)
}

\author{
Author: LOIDE DE OLIVEIRA PONTES \\ Adviser: Prof. DALCIO CARON
}

\section{SUMMARY}

Family producers from Sumaré II's rural establishment - SP were the study object of this work. Social and economical profiles were delineated as well as it has been sought, through a proposed index (Ecological Representation Index - IREc), to analyze the importance of the environment in the activity of a family producer. These analyses were grounded in the field research, centered on variables, obtained from a questionnaire applied in this establishment, along with observations toward acts which happened in agriculture, that contribute to the environment degradation. The application of the index has offered to the researcher a better comprehension from the studied reality. Moreover the results could help in the orientation of acts which could interfere to the transition of the conventional agriculture method to ecological grounded agriculture models. The utilization of IREc facilitates the identification of sustainability local agents, who could carry on the changes toward advanced stages of economical, social and environmental sustainability. 


\section{INTRODUÇÃo}

\subsection{Considerações gerais}

A agricultura familiar constitui-se em um segmento importante e essencial da agricultura brasileira. Segundo um estudo elaborado em conjunto pela Organização das Nações Unidas para a Alimentação e a Agricultura (FAO) e o Instituto de Colonização e Reforma Agrária (INCRA), "Novo Retrato da Agricultura familiar - O Brasil Redescoberto" ${ }^{\prime}$, publicado em 2000, a pequena agricultura tem uma significativa colaboração na produção total de alimentos e emprega a grande maioria dos agricultores. Segundo dados do censo, a agricultura familiar ocupa $30,5 \%$ da área total dos estabelecimentos rurais e concentra apenas $25 \%$ do total de crédito agrícola. Porém, ela agrega $77 \%$ do total de trabalhadores ocupados na agricultura e representa $38 \%$ do valor bruto da produção nacional Este estudo mostra ainda que a área média dos estabelecimentos familiares do Brasil é de 26 ha, sendo que $70 \%$ têm até 20 ha, e $87 \%$ até menos de 50 ha. Na região Sudeste, mais de $60 \%$ dos estabelecimentos familiares têm até 20 ha e $84 \%$ até menos de 50 ha (FAESP, 2002).

Além da importância da agricultura familiar para a economia brasileira, nos últimos anos vem se discutindo a importância do papel do agricultor familiar ${ }^{2}$ para amenizar os problemas ambientais, trazidos pela agricultura convencional.

A transformação da agricultura convencional em agricultura ecologicamente sustentável, com o produtor familiar utilizando os recursos naturais para

\footnotetext{
${ }^{1}$ Este estudo além de definir o universo da agricultura familiar serve, também, como base para delimitar o público a ser beneficiado pelo Programa Nacional de Apoio à Agricultura Familiar - Pronaf.

2 "agricultores familiares são todos aqueles que não empregavam trabalhadores assalariados permanentes e que também não empregavam mais de cinco temporários em algum mês do ano". (Veiga, 1995)
} 
sua sobrevivência, vem trazendo mudanças profundas nas práticas agrícolas. Alguns fatores são enumerados a fim de confirmar esta hipótese, tais como: o uso reduzido de produtos químicos utilizados na lavoura, a implantação de sistemas agro-florestais, a transformação gradual de agricultura tradicional em agricultura orgânica, entre outros.

Esta transformação também vem sendo percebida em alguns assentamentos rurais, como é o caso do Assentamento Sumaré II. Criado em março de 1990, esse assentamento está localizado no Estado de São Paulo entre os municípios de Sumaré e Hortolândia, com um total de 70 hectares, com uma população de 245 habitantes, onde este trabalho foi realizado.

Os moradores do Assentamento Sumaré II, como todo grupo social, têm diferenças individuais, estas diferenças são caracterizadas por fazerem parte de uma mesma classe, lutando por mesmos direitos e realizando trabalhos conjuntos. Por outro lado por terem origens diversas, o que os caracteriza, um a um, como únicos, por serem produtos de grupos sociais diferentes ao longo de sua história de vida. Além disso, estas pessoas também fazem parte de outros grupos sociais além das fronteiras do assentamento, e o intercâmbio de combinações sociais internas e externas é que acaba compondo cada um dos moradores. Isto afeta o modo de pensar e o modo de agir do grupo como um todo.

Este grupo social, com diferenças individuais, realiza ações que são resultados de seu modo de perceber e interpretar o mundo, ou seja, de suas representações sociais. As práticas agrícolas que este grupo social implementa no dia-adia, relacionadas ao meio ambiente e ao modo de pensar ecológico, são os objetos deste trabalho.

Uma contribuição importante à construção social do conceito de meio ambiente é a correspondência entre meio ambiente e ação humana, que tem sido pouco estudada. $O$ objeto desse estudo não é o meio ambiente ou a natureza, mas a ação humana, ou seja, como o produtor familiar utiliza seus conhecimentos sobre o meio ambiente a partir de suas ações cotidianas. Dentre estas ações, são delineados alguns aspectos das formas de gerenciamento dos recursos naturais.

Esse trabalho focaliza, assim, o interesse em pesquisar a realidade 
descrita anteriormente e tem a intenção de refletir sobre este tema. Busca-se em seu objetivo geral: enfocar a questão da representação social do produtor familiar no que se refere ao meio ambiente, natural e construído.

Para tal foram colhidas informações segundo os seguintes objetivos específicos:

- traçar o perfil social e econômico da população local;

- descrever a importância da mata ciliar como prática de conservação;

- compreender a importância, para os produtores, da implantação do sistema Agroflorestal $^{3}$ (SAF) como prática alternativa da atividade agrícola;

- buscar entender, através da criação de um índice, o grau de representação ecológica do produtor familiar do Sumaré II, a partir de práticas e visões que afetam diretamente o meio ambiente em que vive.

O trabalho foi organizado em cinco capítulos: a presente introdução, revisão da literatura, caracterização do assentamento objeto do estudo (incluindo a definição dos métodos e técnicas utilizados), resultados e conclusões.

Na revisão bibliográfica abordam-se conteúdos que auxiliaram o estudo das interações existentes entre o ser humano e o meio ambiente. Muitos elementos foram sendo incorporados pouco a pouco e, por fim, facilitaram uma definição melhor da problemática. Inicialmente discute-se a história da relação homem com o meio ambiente e a crescente e grave ameaça que paira sobre os recursos naturais em todo o mundo, que culminou em grandes reuniões planetárias como a Conferência das Nações Unidas sobre o Meio Ambiente e Desenvolvimento (Rio-92), dentre outras. Segue-se uma abordagem histórica da agricultura e a mudança do pensamento humano nas práticas produtivas, que se destacam pela importância direta para a preservação ou conservação dos recursos naturais. Entendendo a vida como um todo, ou seja, que existe conexão direta e indireta

\footnotetext{
${ }^{3} \mathrm{O}$ termo "agrofloresta" foi criado para designar um uso especial da terra que envolve o manejo intencional de árvores. Através da introdução e mistura de árvores ou arbustos nos campos de produção agrícola ou pecuária, obtémse benefícios a partir das interações ecológicas e econômicas que acontecem nesse processo. Existem muitas variações nas práticas que caem na categoria de agrofloresta: na agrossilvicultura, as árvores são combinadas com culturas agrícolas; em sistemas silvopastoris, elas são combinadas com produção animal e em sistemas agrossilvopastoris o produtor maneja uma mescla de árvores, culturas e animais.
} 
entre a qualidade de vida humana e o uso racional dos recursos naturais, o homem tende a entender melhor a necessidade de preservação da natureza. Resulta disto o aproveitamento dos recursos para que estes sejam explorados de maneira menos prejudicial à natureza, permitindo a harmonia entre o desenvolvimento das atividades humanas e a preservação. Finalizando a revisão bibliográfica, é apresentada a construção do quadro teórico que fundamenta o objetivo deste estudo, intitulado "O Pensamento Humano e Representação Social: elementos para a compreensão da ação humana sobre o meio ambiente". Descreve-se então o conceito central que será trabalhado e que coincide com os pressupostos epistemológicos de vertentes teóricas que pressupõem a construção social da realidade, entre elas a teoria das representações sociais. Entende-se que, de modo geral, as questões ambientais não interrogam unicamente a natureza que se pensa proteger, mas sim a constituição da sociedade. Uma aproximação entre natureza e sociedade incita a repensar a articulação entre estas, percebidas, muito freqüentemente, em termos de oposição. Devido a isso se elegeram teorias que incluem a natureza na análise da sociedade, ao perceber que estas oferecem pistas para compreender as questões de nossa época.

No capítulo seguinte abordam-se os procedimentos metodológicos adotados na pesquisa. $\mathrm{O}$ estudo dos componentes representativos e gerenciais do meio ambiente objetivou, primeiramente, alcançar aspectos de como se particularizam as mediações humanas em relação à problemática ambiental. Assim também a identificar como essa população se posiciona quanto à utilização dos recursos naturais. Finalmente buscou ampliar o conhecimento científico no sentido de oferecer colaboração, visando propor um índice que pudesse melhor visualizar a relação entre o produtor e sua prática produtiva, aprimorando dessa forma aspectos do comportamento da população. À problemática associou-se uma metodologia que visualizou adequada. Organizou-a tendo por meta identificar no discurso da população as suas representações sociais de meio ambiente.

No quarto capítulo são apresentados e discutidos os dados obtidos no trabalho de campo. Ao desvelar um pouco o perfil da população, analisa-se, através do índice proposto, denominado Índice de Representação Ecológica (IREc), como se 
manifesta a natureza para o produtor familiar, através de suas percepções e práticas ao meio ambiente. Esses moradores, como todo ser humano, são produtos e produtores de suas vidas, suas ações constituem-se de um processo dialético, por isso a cultura e a história revelam-se importantes na dinâmica da ação e na elaboração de suas representações sociais. No mundo atual, as representações são um excelente campo de investigação, pois através delas organizam-se os sentidos dados ao mundo. Neste sentido pode-se adiantar que expor o seu processo de elaboração trouxe à tona a forma como estes indivíduos, em interação social, constroem conhecimentos sobre objetos sociais que tornam viáveis a comunicação entre si, assim como a organização dos seus comportamentos.

No último capítulo são apresentadas as considerações finais dessa pesquisa indicando que o seu desenvolvimento firmou-se, desde o início, na expectativa de colaborar na construção de conhecimento.

\subsection{Justificativa}

Diante dos problemas ambientais que o mundo vem sofrendo, o esgotamento dos recursos naturais renováveis e não renováveis, é fundamental entender a questão de como o ser humano se relaciona com o ambiente natural, já que esta interação é essencial para sua sobrevivência. Estudiosos da Revolução Verde ${ }^{4}$ utilizam a analogia de guerra em suas discussões sobre as práticas agrícolas e suas relações com o ambiente. Segundo Butz, citado por Beus \& Dunlap (1988) "nós estamos obtendo progresso, mas devemos lutar com a Mãe-natureza, para desvendar mais de seus segredos e adaptar mais seus recursos em benefício do homem". $\mathrm{Na}$ mesma linha de pensamento, outros autores (McMillen, 1965; Whitten, 1966) descrevem insetos, plantas, e outras pragas como inimigos contra os quais o homem deve declarar guerra se quiser sobreviver. Contrapondo esta idéia, Rodale (1981), dentre outros, vê esta relação adversária com a natureza fútil e autodestrutiva, considerando que lutar contra a natureza poderia levar à destruição do homem. Segundo Toledo (1991), a implementação e

\footnotetext{
${ }^{4}$ ver página 21 .
} 
expansão, durante as últimas décadas, de sistemas produtivos rurais ecologicamente destrutivos e incapazes de realizar uma produção sustentável resulta em diversos fenômenos altamente preocupantes do ponto de vista ambiental. Frente a isto, a realização de estudos que poderíamos chamar de reavaliação ecológica dos sistemas produtivos é de relevante importância.

Outro fator que deve ser discutido é a aparente contradição em ser pequeno produtor rural frente à política sócio-econômica de desenvolvimento adotada em nosso país. Segundo Silva (1980), a questão agrária brasileira vem sendo agravada pelo modo como tem se expandido as relações capitalistas de produção no meio rural. A maior exigência e controle de capital na produção agrícola, a industrialização dos processos de produção no campo e a crescente especialização, em detrimento da diversidade de produção, têm causado impactos sociais negativos, muitas vezes conduzindo a uma proletarização das classes rurais menos privilegiadas. Um dos impactos sociais desta política agrícola conduz à expropriação da terra dos pequenos produtores independentes, levando-os à condição de assalariados ou "bóias-frias", contribuindo para o aumento demográfico em ambientes urbanos.

É neste contexto que Bergamasco \& Norder $(1996$, p.8) enfatizam a importância dos assentamentos como alternativa para melhoria de vida do pequeno produtor. Segundo os autores: “ (...) os assentados rurais representam uma importante iniciativa no sentido de gerar empregos diretos e indiretos a baixo custo e para desenvolver um modelo de desenvolvimento agrícola $\mathrm{em}$ bases sociais mais eqüitativas

É importante nesta justificativa também focalizar as estratégias de sobrevivência do pequeno agricultor familiar que, para contribuir para a limitação da produção predatória, utiliza o ecoturismo ou turismo rural como mais uma alternativa para geração de renda.

Como observa Kitamura (1997, p.128) "o ecoturismo pode, em especial, favorecer a criação de empregos não-agrícolas nas áreas rurais, facilitar a articulação do rural com o urbano além de constituir-se em fonte de financiamento da preservação do ambiente". Reforçando a idéia da necessidade de uma maior integração do pequeno agricultor com a natureza, Sawyer (1990) observa que: 
"a viabilização e dinamização da pequena produção agrícola seriam facilitadas se os camponeses e os grupos políticos e intelectuais que os apóiam procurassem formar alianças com o movimento ecológico nacional e internacional, como fizeram os seringueiros, em vez de minimizar ou ignorar os problemas ambientais da pequena produção".(Sawyer,1990, p.76)

No que se refere a melhor entender a ação humana sobre o meio ambiente, as representações sociais dentro do cotidiano traduzem em conhecimento prático e popular as informações veiculadas na vida social, o que faz com que a realidade se materialize nas ações dos sujeitos. E é no plano individual que as representações se manifestam.

Pôde-se melhor abstrair essa discussão na obra de Delval (2001) onde ele diz que, desde criança, o homem forma em sua mente algo que podemos definir como representações ou modelos de realidade. Esses se modificam à medida que se amplia a experiência do sujeito, sendo substituído por outros melhores, ou seja, com mais poder explicativo, os quais geralmente são bastante adequados. Além disso, o sujeito constrói representações da realidade por meio da resistência que esta oferece à suas ações.

As resistências da realidade podem levar o homem a dois caminhos: ou ele modifica seus esquemas, mantendo seus objetivos iniciais, ou então modifica seus objetivos. No primeiro caso, diz-se que o sujeito se acomoda à realidade vigente, mudando seus esquemas. No segundo caso, diz-se que os esquemas não podem assimilar a realidade, e assim outros objetivos são buscados dentro dos esquemas vigentes. (ibidem p.46-47)

Para Kuhnen (2001), no campo das ciências humanas, o fenômeno das representações talvez seja na atualidade um dos temas que mais tem aproximado perspectivas teóricas. Diversas correntes têm buscado compreender como se elabora ou se engendra esta característica humana. Encontramos na maioria delas a noção de construção do real, ou seja, o caráter generativo do conhecimento cotidiano, que exige uma análise dos atos de comunicação e da interação entre indivíduos, ou mesmo grupos 
e instituições. A esta comunicação é creditado o papel de mecanismo através do qual se transmite, cria e objetiva a realidade. Entra em jogo aí um processo psicológico que mediatiza a relação indivíduo/meio, processo entendido como essencialmente representativo.

Para a autora, o conceito de representação não é simples e nem consensual. Talvez a questão mais aglutinadora seja que o acesso à representação vincula-se ao conhecimento que transcende a aparência das coisas. Ao entendê-la assim, quase todos os aportes teóricos voltam-se para o cotidiano ou o vivido, centrando aí sua fonte de conhecimento.(ibidem p.78) 


\section{REVISÃO BIBLIOGRÁFICA}

\subsection{O homem e sua relação com a natureza}

Régnier (2001), ao discutir a relação homem com a natureza, coloca que os nossos antepassados viviam em harmonia com a natureza. Entretanto, deve-se observar que eles buscavam sua sobrevivência e mantinham estreito contato com a natureza, de tal forma que a preservação das espécies e esta harmonia pode ser apenas reflexo da autopreservação, ou ainda da busca por novas terras mais férteis e com maior abundância de caça e pesca. Além disso, a relação entre a disponibilidade de matéria prima (comida, em especial) e o tamanho populacional era francamente favorável. Talvez o afastamento do homem da sua forma básica de sustento, ou seja, da natureza, resultado da Revolução Industrial, tenha contribuído significativamente para esta insensibilidade que resultou no alerta dado, em especial a partir de meados do século $\mathrm{XX}$, relativo à possibilidade de um desequilíbrio ambiental, com a escassez dos recursos hídricos.

Lima (1984) comenta que a relação do homem com a natureza, a princípio um processo passivo, assume posições mais agressivas, à medida que as comunidade progrediram na acumulação de conhecimentos e em sua organização. Exemplo bastante significativo é dado inclusive pelos homens que habitavam o Pleistoceno. Já na idade da pedra lascada, eles confeccionaram ferramentas, aprenderam a controlar o fogo e a agir em conjunto para assegurar o sustento. A descoberta do fogo representou o primeiro passo de emancipação do homem.

“O homem primitivo não provocava desequilíbrio apreciável sobre os processos metabólicos e reprodutivos, que regulavam o sistema de suporte da vida na biosfera, uma vez que as alterações eram numa escala que permitia a manutenção dos 
limites de estabilidade. (...) $O$ trabalho fez com que, paulatinamente, tomasse para si a responsabilidade dos limites de sobrevivência, desde que ampliou sua habilidade dos limites de explorar os recursos naturais. À medida que observava os fenômenos da natureza, procurava reproduzi-los e acumulava conhecimento. Elaborando e aplicando o conhecimento, desenvolvia sua criatividade na busca para eliminar as barreiras encontradas". (Lima,M.J., 1984, p.27)

Para a autora, o segundo passo de emancipação do homem foi a descoberta da agricultura. Foi através desta que ampliou seu ambiente, aumentou e controlou as possibilidades de alimentos, facilitando, assim, o aumento da população. Posteriormente manufaturando a matéria prima, começou a produzir com dupla finalidade: subsistência e manutenção de um novo sistema de produção. Essa fase determinou um aumento na utilização de recursos naturais, provocou mudanças de valores na sociedade, além de induzi-las à criação de ambientes artificiais. $\mathrm{O}$ resultado foi o aumento da dominação e agressividade do homem sobre a natureza. (ibidem, p.2728)

No que se refere à ação humana sobre o meio ambiente no Brasil, Melo (2002) faz um cronograma de evidência da agressão do homem à natureza desde sua descoberta:

- "No ano de 1505, Fernão de Noronha inicia a comercialização de pau-brasil, no início um monopólio da coroa portuguesa. Em seguida participa a Inglaterra, a França, a Espanha e a Holanda. Atualmente a pilhagem continua (Japão, Inglaterra e EUA). Dos $200.000 \mathrm{~km}^{2}$ da Mata Atlântica originais, restam apenas 10.000 $\mathrm{km}^{2}(5 \%)$, que continuam ameaçados.

- No ano de 1542, a primeira Carta Régia do Brasil estabelece normas disciplinares para o corte de madeira e determina punições para os abusos que vinham sendo cometidos.

- Em 1822, José Bonifácio de Andrade e Silva (o patriarca da Independência, ao tempo das lutas contra a repressão portuguesa 
nos movimentos de independência do Brasil), como ministro do reino e dos negócios estrangeiros, e como político de impressionante visão, revela-se também um naturalista. Foram feitas por ele as primeiras observações de cunho ecológico em nosso país.

- Em 1827, a Carta de Lei de Outubro, do Império, delega poderes aos juízes de paz das províncias para a fiscalização das matas.

- Em 1849, o naturalista inglês Henry Wallace Bates percorre a Amazônia e recolhe oito (8) mil espécies de plantas e animais. A sua coleção, levada, para a Inglaterra, subsidia Charles Darwin nos seus estudos. Wallace foi o naturalista estrangeiro que permaneceu mais tempo nos trópicos (1849-1859).(In Amazônia urgente, pg 172).

- Em 1850, D. Pedro II edita a lei 601, proibindo a exploração florestal em terras descobertas e dando poderes às Províncias, para sua aplicação. $\mathrm{Na}$ época, a lei é ignorada e verifica-se uma grande devastação de florestas (desmatamento pelo fogo) para a instalação de monocultura - café - para alimentar as exportações brasileiras.

- Em 1863 Thomas Huxley no seu ensaio "Evidence as to Man's Place in nature" (Evidência da posição ocupada pelo homem na natureza) trata da interdependência entre os seres humanos e os demais seres vivos.

- Eugênio Warning, botânico dinamarquês, desenvolve, em Lagoa Santa-MG, estudos do ambiente de cerrado, e publica-os em 1892. São os trabalhos precursores para o primeiro livro sobre ecologia (1895) de sua autoria.

- Em 1864 George Perkin Marsh (1801-1882) diplomata americano, publica o livro "Man and or Physical Geography by Human Action" (O homem e/ou a geografia física sob a ação humana). 
Considerado o primeiro exame detalhado da "erosão da natureza provocado pelo homem", Marsh documenta como os recursos do planeta estavam sendo reduzidos e prevê que tal exploração não continuaria sem exaurir, inevitavelmente, a generosidade da natureza; analisa as causas do declínio de civilizações antigas e prevê um destino semelhante para as civilizações modernas, se não houver mudanças.

- No ano de 1869, o biólogo alemão, Ernt Heckel (1834-1919) propõe o vocábulo "ecologia" para os estudos das relações entre as espécies e o seu meio ambiente. Já em 1866, este biólogo sugere, em sua obra Morfologia Geral dos Organismos, a criação de uma nova disciplina para estudar tais relações. Inspirado no livro de Marhs (1864), é criado nos Estados Unidos o primeiro parque nacional do mundo - Yellowstone National Park; no Brasil, a princesa Isabel autoriza a operação da primeira empresa privada especializada em corte de madeira. $\mathrm{O}$ ciclo econômico do paubrasil encerra-se em 1875, com o abandono das matas exauridas" (Melo, 2002).

Ainda sobre esta discussão, Ferri (1977, p.113-114) comenta que em 1557 foi publicado na Alemanha o livro de Hans Staden, que descreve sua viagem pelo Brasil e responsabiliza os índios brasileiros pela devastação da natureza, citando os manejos adotados - derrubada da mata, uso do fogo, práticas agrícolas, de caça, de pesca, etc.

Mas, só a partir da década de 60 (do século XX), a deterioração ambiental e sua relação com o estilo de crescimento econômico realmente começaram a ser objeto de estudo, e a construção do conhecimento social que se refere ao meio ambiente se torna preocupação internacional. Neste período emergem, com a contra-cultura, uma série de movimentos sociais trazendo, não só a crítica ao modelo dominante de produção, mas também ao modo de vida dele derivado. Surgem, então, movimentos sociais como os das mulheres, dos negros e, entre eles, os movimentos ecológicos antes 
dispersos (Roszak, 1994).

Outros fatos também marcaram a preocupação do homem com o ambiente natural. Cita-se, por exemplo, o livro "Primavera Silenciosa", de Rachel Carson, lançado em 1962 e, a partir de 1968, o clube de Roma começa a trabalhar na série de seus famosos relatórios científicos. (Leis \& D'Amato, 1995, p.80). Este livro segundo Diegues (2000):

"foi particularmente importante por ter feito uma critica severa contra o uso de biocidas, base da possante agroindústria americana. Ao concluir Silent Spring, Carson constatou que o controle da natureza é uma sentença concebida na arrogância, nascida na idade neandertalense da biologia e da filosofia, quando se supunha que a natureza existia para conveniência do homem" (Diegues,2000, p.28).

A partir dos anos 70 fortalece-se a noção de limitação dos recursos naturais, com receio de sua exaustão e dos estragos causados pela crescente poluição. Neste sentido, Brügger (1999) menciona que

"na década de 70, predominava no 'inconsciente coletivo' mundial a idéia de que a chamada crise ambiental se devia, sobretudo, à exaustão dos recursos naturais, à poluição, etc. Poucos eram os que se aventuravam a destacar os aspectos sociais dessa crise. Até aquela década, vivenciava-se ainda, em nível planetário, o fim de uma certa prosperidade por uma ciência e uma tecnologia - 'boas em si’ que são cada vez mais questionadas" (Brügger,1999, p.29).

Em 1972, o Clube de Roma publicou o conhecido relatório "Limites do Crescimento", que denunciava o crescente consumo mundial. Este ocasionaria um limite de crescimento e um possivel colapso (Leis, 1991, p.91). Devido ao grande impacto 
polêmico deste relatório, no ano de 1972, a ONU organizou a Primeira Conferência Mundial do Meio Ambiente Humano em Estocolmo, na Suécia. Estiveram presentes representantes de 58 países, inclusive do Brasil (Ferri 1997, p.138-139).

Neder (1994) comenta que, nessa conferência, uma estratégia para resolver os problemas ambientais estava voltada na educação do homem para o uso mais equilibrado dos recursos. Estocolmo foi o fórum que iniciou a discussão sobre o ecodesenvolvimento, noções de onde se definiria mais tarde no Relatório de Brutdland (Nosso Futuro Comum, 1991) a idéia de sustentabilidade, ou desenvolvimento sustentável.

Das grandes ações humanas que afetaram o meio ambiente, podemos citar a poluição e a questão da chuva ácida na Europa. Essas ações levaram para a Conferência de Estocolmo a reflexão, de forma mais ampla, das questões políticas, sociais e econômicas envolvidas. "(...) onde as recomendações passaram a ser mais realistas e mais próximas da vida e da qualidade da vida humana" (Maimon, 1992, p.57).

Como resultado deste evento, foi criado o Programa de Meio Ambiente das Nações Unidas - UNEP, encarregado de monitorar o avanço dos problemas ambientais no mundo. $\mathrm{Na}$ continuidade, proliferaram acordos e conferências temáticas internacionais, como por exemplo, a Convenção sobre o Comércio Internacional de Espécies Ameaçadas da Fauna e Flora Silvestres (CITES, em 1973), e o Programa Internacional de Proteção a Produtos Químicos (1980), estabelecido pela Organização Mundial da Saúde (OMS), UNEP e Organização Internacional do Trabalho (OIT), objetivando avaliar os riscos causados à saúde humana e ao meio ambiente. Em $1984 \mathrm{em}$ Versalhes, ocorre a I Conferência sobre o meio ambiente da Câmara do Comércio Internacional, com o objetivo de estabelecer formas de colocar em prática o conceito de “desenvolvimento sustentável" (Maimon, 1992).

Em 3 de dezembro do mesmo ano, em Bhopal, Índia, ocorre o mais grave acidente industrial do mundo, quando o gás venenoso - menthyl isocyanate - vaza da fábrica da Union Caribe, matando mais de 2 mil pessoas e ferindo outras $200 \mathrm{mil}$. Tal acidente, segundo Petula, iniciou o período moderno da política ambiental (Petula, citada por Melo, 2002). 
Nos anos 90, o Brasil começa a se transformar no palco dos debates da Rio-92, por meio dos preparativos ao Fórum Global sobre Educação Ambiental, realizados pelas ONGs e movimentos sociais. O conceito de desenvolvimento sustentável ganha espaço no discurso dos órgãos internacionais à partir do relatório Bruntdland (Nosso Futuro Comum). Desenvolvimento sustentável foi definido pela Comissão Mundial sobre Meio Ambiente e Desenvolvimento como:

"O 'desenvolvimento que satisfaz as necessidades presentes sem comprometer a capacidade das gerações futuras de suprir suas próprias necessidades'. Muitos consideram essa idéia ambígua, permitindo interpretações contraditórias. Porque desenvolvimento pode ser entendido como crescimento, e crescimento sustentável é uma contradição: nenhum elemento físico pode crescer indefinidamente. Nas propostas apresentadas pelo Programa das Nações Unidas para o Meio Ambiente (Pnuma), emprega-se o termo 'desenvolvimento sustentável' significando 'melhorar a qualidade da vida humana dentro dos limites da capacidade de suporte dos ecossistemas'. Isso implica, entre outros requisitos, o uso sustentável dos recursos renováveis - ou seja, de forma qualitativamente adequada e em quantidades compatíveis com sua capacidade de renovação" (Brasil, 2002, p.12).

O Pnuma ${ }^{5}$, com o apoio da ONU e de diversas organizações nãogovernamentais, propôs, em 1991, princípios, ações e estratégias para a construção de uma sociedade sustentável. $\mathrm{Na}$ formulação dessa proposta emprega-se a palavra "sustentável" em diversas expressões: desenvolvimento sustentável, economia sustentável, sociedade sustentável e uso sustentável. Parte-se do princípio que: se uma atividade é sustentável, para todos os fins práticos ela pode continuar indefinidamente.

\footnotetext{
${ }^{5}$ Programa das Nações Unidas para o Meio Ambiente - Instituto Brasil PNUMA é uma entidade privada sem fins lucrativos.
} 
Contudo, não pode haver garantia de sustentabilidade a longo prazo porque muitos fatores são desconhecidos ou imprevisíveis.

Diante disso, propõe-se que as ações humanas ocorram dentro das técnicas e princípios conhecidos de conservação, estudando seus efeitos para que se aprenda rapidamente com os erros. Este processo exige monitorização das decisões, avaliação e redirecionamento da ação; e muito estudo. Portanto, traz implicações para o trabalho dos professores e responsabilidades para a escola como uma das instâncias da sociedade que pode contribuir para o mesmo processo.

Uma sociedade sustentável, segundo o mesmo Programa, é aquela que vive em harmonia com nove princípios interligados apresentados a seguir.

- "Respeitar e cuidar da comunidade dos seres vivos (princípio fundamental). Trata-se de um princípio ético que "reflete o dever de nos preocuparmos com as outras pessoas e outras formas de vida, agora e no futuro".

- Melhorar a qualidade da vida humana (critério de sustentabilidade). Este é o verdadeiro objetivo do desenvolvimento, ao qual o crescimento econômico deve estar sujeito: permitir aos seres humanos "perceber o seu potencial, obter autoconfiança e uma vida plena de dignidade e satisfação".

- Conservar a vitalidade e a diversidade do Planeta Terra (critério de sustentabilidade). $O$ desenvolvimento deve ser tal que garanta a proteção "da estrutura, das funções e da diversidade dos sistemas naturais do Planeta, dos quais temos absoluta dependência".

- Minimizar o esgotamento de recursos não-renováveis (critério de sustentabilidade). São recursos como os minérios, petróleo, gás, carvão mineral. Não podem ser usados de maneira "sustentável" porque não são renováveis. Mas podem ser retirados de modo a reduzir perdas e principalmente a minimizar o impacto ambiental. Devem ser usados de modo a "ter sua vida prolongada como, por exemplo, através de reciclagem, pela utilização de menor quantidade na obtenção de 
produtos, ou pela substituição por recursos renováveis, quando possível".

- Permanecer nos limites de capacidade de suporte do Planeta Terra (critério de sustentabilidade). Não se pode ter uma definição exata, por enquanto, mas sem dúvida há limites para os impactos que os ecossistemas e a biosfera, como um todo, podem suportar sem provocar uma destruição arriscada. Isso varia de região para região. Poucas pessoas consumindo muito podem causar tanta destruição quanto muitas pessoas consumindo pouco. Deve-se adotar políticas que desenvolvam técnicas adequadas e tragam equilíbrio entre a capacidade da natureza e as necessidades de uso pelas pessoas.

- Modificar atitudes e práticas pessoais (meio para se chegar à sustentabilidade). "Para adotar a ética de se viver sustentavelmente, as pessoas devem reexaminar os seus valores $\mathrm{e}$ alterar $\mathrm{o}$ seu comportamento. A sociedade deve promover atitudes que apóiem a nova ética e desfavoreçam aqueles que não se coadunem com o modo de vida sustentável".

- Permitir que as comunidades cuidem de seu próprio ambiente (meio para se chegar à sustentabilidade). É nas comunidades que os indivíduos desenvolvem a maioria das atividades produtivas e criativas. E constituem o meio mais acessível para a manifestação de opiniões e tomada de decisões sobre iniciativas e situações que as afetam.

- Gerar uma estrutura nacional para a integração de desenvolvimento e conservação (meio para se chegar a sustentabilidade). A estrutura deve garantir "uma base de informação e de conhecimento, leis e instituições, políticas econômicas e sociais coerentes". A estrutura deve ser flexível e regionalizável, considerando cada região de modo integrado, centrado nas pessoas e nos fatores sociais, econômicos, técnicos e políticos que influem na sustentabilidade dos processos de geração e distribuição de riqueza e bem-estar. 
- Constituir uma aliança global (meio para se chegar à sustentabilidade). Hoje, mais do que antes, a sustentabilidade do planeta depende da confluência das ações de todos os países, de todos os povos. As grandes desigualdades entre ricos e pobres são prejudiciais a todos."A ética do cuidado com a Terra aplica-se em todos os níveis, internacional, nacional e individual. Todas as nações só têm a ganhar com a sustentabilidade mundial e todas estão ameaçadas caso não consigamos essa sustentabilidade".

Desde então, a palavra sustentabilidade vem ganhando um interesse significativo entre cientistas, administradores, políticos, movimentos sociais. Constituise em um conceito dinâmico, que segundo SACHS (1986, p.58-59), pode adquirir cinco dimensões principais:

a) Sustentabilidade social, que busca o estabelecimento de um padrão de desenvolvimento que conduza a uma distribuição mais equitativa da renda, assegurando uma melhoria dos direitos das grandes massas da população e uma redução das atuais diferenças entre os níveis de vida daqueles que tem e daqueles que não tem.

b) Sustentabilidade econômica, possível através de inversões públicas e privadas e da alocação e do manejo eficiente dos recursos naturais.

c) Sustentabilidade ecológica, entendida como aumento da capacidade de suporte do planeta, mediante intensificação do uso do potencial de recursos disponíveis, compatível com um nível mínimo de deterioração deste potencial. Reduzir o consumo de combustíveis fósseis; de substâncias poluente; mediante adoção de políticas de conservação de energia e de recursos; reciclagem; substituição por recursos renováveis e/ou abundantes e inofensivos. O desenvolvimento de tecnologias capazes de gerar um mínimo de dejetos e um máximo de eficiência em termos de recursos utilizados; estímulo à agricultura biológica e aos sistemas de agrosilvicultura.

d) Sustentabilidade geográfica, buscando uma configuração urbano-rural 
mais equilibrada, evitando a concentração da população em áreas metropolitanas ou assentamentos humanos em ecossistemas frágeis.

e) Sustentabilidade cultural, que possivelmente seja a dimensão mais difícil de ser concretizada, em função da multiplicidade de vias de acesso à modernidade. $\mathrm{O}$ desenvolvimento sustentável só é possível numa pluralidade de soluções locais e adaptadas a cada ecossistema, utilizando-se como paradigma os sistemas de produção elaborados pelo homem, aplicando-se a racionalidade camponesa no nível mais elevado da espiral do conhecimento humano.

E, por fim, a descrição feita por Keith Thomas no livro O Homem e o Mundo Natural (1989) é, com certeza um belo exemplo de uma ordem de estudos históricos, que buscam explicitar aspectos sensíveis das ações do homem com a natureza ou com o seu habitat. $O$ trabalho de Thomas esclarece que o interesse pelo ambiente natural e as preocupações com a relação entre o homem e as outras espécies são fenômenos recentes, que por sua vez trouxeram novidades concernentes ao direito, antes garantido, de explorar espécies a fim de proporcionar benefícios pessoais. E essa corrente de representação ambiental indica que o predomínio humano sobre o mundo da natureza começou a ser contestado inclusive na agricultura.

\subsection{Agricultura: repensando o meio ambiente}

\subsubsection{Breve histórico da evolução da agricultura}

De todas as atividades humanas, a agricultura é a que ocupa as maiores áreas terrestres, uma das que mais provocam ao homem diferentes representações que levaram grandes modificações no meio ambiente. Rosa (1998), ao discutir a relação do homem com a terra, diz que nas sociedades primitivas (caçadores e coletores) o homem já produzia pequenas intervenções na natureza, e, com o advento da agricultura, este grau de interferência humana aumentou, a ponto de provocar mudanças radicais em todos os elementos bióticos e abióticos do ambiente natural. 
A agricultura surgiu há cerca de um milhão e quinhentos anos. Paterniani (2001) comenta que a "espécie humana passou a maior parte deste período enfrentando toda sorte de adversidades, incluindo uma forte competitividade com outras espécies". Segundo o autor, a maior dificuldade foi garantir a disponibilidade de alimentos. "Para sobreviver, o homem teve que lutar como caçador e colhedor de plantas por várias vezes esteve a ponto de enfrentar a própria extinção, conforme salienta Norman Borlaug, o pai da Revolução Verde".

A agricultura é uma atividade bastante recente na história, as plantas começaram a ser cultivadas e domesticadas há cerca de 10 mil anos atrás e segundo as evidências, a iniciativa partiu das mulheres que ao serem encarregadas das tarefas domésticas, por serem menos aptas para a caça, puderam observar e desenvolver conhecimento sobre sua utilização, propriedades e sua reprodução. Tal relação com o meio físico é, com certeza, a expressão de uma nova representação social sobre a terra que veio influenciar novas atividades agrícolas.

Apesar do advento da agricultura, a disponibilidade de alimento sempre fez parte da preocupação da raça humana. Encontramos, em 1798, na teoria da população de Robert Malthus uma previsão catastrófica no que se refere a fome no mundo. Segundo ele: "se não for a população contida por freio algum, irá ela dobrando de 25 em 25 anos, ou crescerá em progressão geométrica $(1,2,4,8,16 \ldots$...).Pode-se afirmar, dadas as atuais condições médias da terra, que os meios de subsistência, nas mais favoráveis circunstâncias, só poderão aumentar, no máximo em progressão aritmética..O essencial dessa teoria é o seguinte: "Há uma falta de concordância entre o poder de reprodução da espécie humana e a capacidade de produção dos meios de subsistência. $O$ excedente deve desaparecer: um homem que nasce em um mundo já ocupado não tem direito de reclamar parcela alguma de alimento. No banquete da natureza intima-o a sair e não tarda em executar essa intimação" (Malthus citado por Hugon,1969).

A escassez de alimentos tornou-se uma preocupação permanente na vida do homem. Devido a isso, inúmeros progressos técnico-científicos foram aplicados na agricultura, garantindo, assim, a sobrevivência da espécie humana como também a libertando da necessidade de ser nômade. Pode-se tomar como exemplo deste progresso 
científico a Revolução Verde, que na época foi tão elogiada e hoje tão contestada.

O programa da Revolução Verde teve duas fases: a pioneira, de 1943 a 1965, e a grande expansão, de $1965 \mathrm{em}$ diante. A primeira fase teve um caráter pioneiro e experimental. Os projetos pilotos foram no México, nas Filipinas e no Brasil, além dos Estados Unidos, resultando em pacotes tecnológicos. De acordo com Aguiar (1986, p.42), pacote tecnológico é um "conjunto de técnicas, práticas e procedimentos agronômicos que articula entre si e que são empregados indivisivelmente numa lavoura ou criação, seguindo padrões estabelecidos pela pesquisa".

$\mathrm{Na}$ segunda fase, como objetivo de difundir os pacotes tecnológicos, ocorreu uma intervenção controlada no processo de produção agrícola da produção, sobretudo em relação ao uso de semente, adubos e equipamentos e controle de articulação dos produtores, através de assistência técnica e orientação de crédito rural (Brum, 1988:45, apud Zamberlam \& Froncheti.2001).

No Brasil, a Revolução Verde se deu na década de 60 e o avanço da agricultura e a importância cada vez maior dada às necessidades humanas (de consumo, não só as reais necessidades de subsistência) e à sua oferta, fez surgir uma agricultura de produção em escala. Para o aprimoramento desta produção foram elaborados métodos, ferramentas e formas de gerenciamentos cada vez mais sofisticados. Paralelamente a isto, desastres ambientais, que tiveram repercussões mundiais, serviram para mostrar as limitações no trato com o meio ambiente trazendo profundas seqüelas: alto custo social, econômico e ambiental, efeitos nocivos sobre a população por contaminação e envenenamento do solo, ar e água, destruição do equilíbrio natural dos ecossistemas por erosão e morte dos solos, desaparecimento dos inimigos naturais das pragas, êxodo rural, dentre outras.

Com todos os esforços da tecnologia, à base de alto uso de agrotóxico, aplicada na agricultura, a Organização das Nações Unidas para a Alimentação e a Agricultura - FAO em 1996 reconheceu o fracasso da Revolução Verde como sistema que pretendia resolver a fome no mundo, propondo na Conferência de Alimentação uma nova Revolução Verde ou Alternativa (produção de alimento sem contaminação) (Zamberlam \& Froncheti, 2001). 
Como já mencionado anteriormente, a Comissão Mundial do Meio Ambiente e Desenvolvimento (World Commission Environment and Development) definiu Desenvolvimento Sustentável como "Desenvolvimento que atende às necessidades do presente, sem comprometer a capacidade de gerações futuras de fazer face às suas próprias necessidades". Frente a essa definição o Conselho de Alimentos e Organização Agrícola das Nações Unidas (Council of Food and Agriculture Organizacion of the United Nations - FAO) adotou a seguinte definição de Desenvolvimento Agrícola Sustentado (SAD):

"Desenvolvimento Agrícola Sustentado é o gerenciamento e conservação da base dos recursos naturais e orientação da mudança tecnológica e institucional, assegurando a realização e satisfação continuada das necessidades humanas para gerações presentes e futuras. Este desenvolvimento sustentado (nos setores agrícola, florestal e pesqueiro) conserva os recursos genéticos da terra, água, vegetação e animal, não degrada o meio ambiente, é apropriado, viável economicamente e aceitável socialmente" (FAO, 1991).

Dentro do seu marco conceitual, a Agenda 21Brasileira ${ }^{6}$ observa que:

"A idéia de uma 'agricultura sustentável' revela, antes de tudo, a crescente insatisfação com o status quo da agricultura moderna. Indica o desejo social de práticas que, simultaneamente, conservem os recursos naturais e forneçam produtos mais saudáveis, sem comprometer os níveis tecnológicos já alcançados de segurança alimentar. Resulta de emergentes pressões sociais por uma agricultura que não prejudique o meio ambiente e a saúde" (Agenda $21-1999)$.

\footnotetext{
${ }^{6}$ Agenda 21 Brasileira - Área Temática: Agricultura Sustentável - Ministério do Meio Ambiente - 1999
} 
Deveria ter as seguintes características:

- manutenção, a longo prazo, dos recursos naturais e da produtividade agrícola;

- mínimo de impactos adversos ao meio ambiente;

- retornos adequados aos produtores;

• otimização da produção com um mínimo de insumos externos;

- satisfação das necessidades humanas de alimentos e renda;

-atendimento às necessidades sociais das famílias e das comunidades rurais.

Nos dias atuais, vivenciamos um processo de "ecologização da sociedade", diversos segmentos sociais vão, aos poucos, inserindo-se no movimento ecológico, motivados por diferentes fatores, abrangendo diversidades ideológicas e partindo de diferentes lugares, com diferentes ideologias a orientar seus discursos e suas práticas. De acordo com Viola \& Leis (1991), este processo de "ecologização da sociedade" é uma tendência histórica da sociedade ocidental e nenhum país estará imune a ele, embora a evolução da consciência ambiental dependa das particularidades de cada país.

A agricultura mundial também estaria experimentando este processo de transição (processo de ecologização), que corresponde à introdução de valores ambientais nas práticas agrícolas. Este processo constitui uma força sócio-ecológica combinada, a partir da qual as considerações de caráter sócioambiental e biofísico assumem papel ativo na determinação das tecnologias agrícolas. $O$ importante neste processo de ecologização é que o homem retoma sua visão de mundo. Esta permite dar um novo sentido às suas condutas e compreender a realidade no mundo em que está inserido.

2.2.2 Conceitos teóricos: o pensamento humano e representação social elementos para compreensão da ação humana sobre o meio ambiente 
Nesta parte do trabalho, o objetivo é apresentar as noções teóricas que sustentam o estudo, cujo foco principal é a ação humana, no que se refere ao meio ambiente.

De forma inicial, propõe-se tratar a definição conceitual de meio ambiente. Para isso, foi feito o caminho já percorrido por Reigota (1998) que elencou uma série de definições de alguns autores. Tais definições sobre meio ambiente são:

" "(...) o que circunda um organismo, incluindo as plantas e os animais, com os quais ele interage"7.

"“(..) o meio ambiente se compõe de dois aspectos: a) meio ambiente abiótico, físico e químico e b) meio ambiente biótico". 8

" O conjunto de fatores bióticos (os seres vivos) ou abióticos (físicoquímicos) do habitat, são suscetíveis de terem efeitos diretos ou indiretos sobre os seres vivos e, compreende-se, sobre o homem"?.

"“O que circunda um indivíduo ou um grupo. A noção de meio ambiente engloba, ao mesmo tempo o meio ambiente cósmico, geográfico, físico e o meio ambiente social, com suas instituições, sua cultura, seus valores. Esse conjunto constitui um sistema de forças que exerce sobre o indivíduo e nas quais ele reage de forma particular, segundo os seus interesses e suas capacidades" 10 .

Reigota (1998) propõe em sua definição que o meio ambiente é:

"O lugar determinado ou perdido, onde os elementos naturais e sociais estão em relação dinâmica e em interação. Essas relações implicam processos de criação cultural e tecnológica e processos históricos e sociais de transformação do meio natural e construído" (ibidem:14).

\footnotetext{
${ }^{7}$ Rickles (1973, p.78) citado por Reigota (1998)

${ }^{8}$ Duvigneaud (1984, p.237) citado por Reigota (1998)

${ }^{9}$ Touffet (1988) citado por Reigota (1998)

${ }^{10}$ Silliamy (1980) citado por Reigota (1998)
} 
O autor deixa implícito, nessa definição, que meio ambiente é um espaço determinado no tempo, no sentido de se procurar delimitar as fronteiras e os momentos específicos que permitem um conhecimento mais aprofundado. Ele também é percebido, já que cada pessoa o delimita em função de suas representações, conhecimento específico e experiência cotidiana nesse mesmo tempo e espaço. No que se refere às relações dinâmicas e interativas, elas indicam a constante mutação, como resultado da dialética das relações entre grupos sociais e o meio natural e construído, implicando um processo de criação permanente, que estabelece e caracteriza culturas em tempo e espaços específicos. (ibidem: pp 14-15)

Esta definição de meio ambiente dada por Reigota é ancorada em Moscovici (1978) onde "representação social é o senso comum que se tem sobre um determinado tema, onde se incluem também os preconceitos, ideologias e características das atividades cotidianas (sociais e profissionais) das pessoas".(Reigota, p.12)

A questão relevante, no que toca a relação entre o meio ambiente e sua forma de representação por parte dos vários atores sociais, é que o meio ambiente é percebido de forma plural e diferenciada. $\mathrm{E}$ isso se dá pelo fato dos indivíduos compreendê-lo a partir de uma perspectiva subjetiva, ancorada numa realidade concreta.

Dentro desse contexto, é fato que o meio ambiente é enfatizado como uma determinação natural (por mais subjetiva que seja sua compreensão). É sobre essa compreensão que se fundamenta uma prática social, cultural e política por parte dos atores sociais. Pode-se inclusive afirmar que, pelo fato dos indivíduos compreenderem de forma simples a relação intrínseca entre o natural e o humano, nas representações sociais sobre o meio ambiente, percebe-se que um só tem sentido quando conjugado ao outro. Pelo menos é o que demonstra a análise da pesquisa feita por Reigota ${ }^{11}$ (1997).

Enquanto material de estudo, a representação social é importante como base para o entendimento deste trabalho, já que foi verificada a ação do homem no que diz respeito ao meio ambiente. Tal definição é necessária, já que se pretende trabalhar

${ }^{11}$ Nesse livro, que tem como título Meio ambiente e Representação social, Marcos Reigota faz uma análise sobre o conceito de meio ambiente a partir da forma como educadores compreendem e definem o meio ambiente, e como esse contexto de definição está ancorado na prática cotidiana de relação prática e conceitual do mesmo. 
com indivíduos, que por sua vez recebem influências do(s) grupos(s) a que pertence(m).

$O$ conceito de representação social que este trabalho utiliza como orientação para sua análise é obtido através do termo filosófico que significa reprodução de uma percepção anterior ou do conteúdo do pensamento.

"Nas ciências sociais são definidas como categorias de pensamento que expressam a realidade, explicam-na, justificando-a ou questionando-a. Essas percepções são consideradas consensualmente importantes, atravessando a história e as mais diferentes correntes de pensamento sobre o social" (Minayo, 1992, p.158).

Do ponto de vista sociológico, Durkheim (1968) foi o primeiro a trabalhar explicitamente o conceito de representação social, que ele denominou representação coletiva. Para este autor, a vida coletiva é integrada pelos fatos sociais e a consciência coletiva de que esta dotada é, por sua vez, integrada por representações coletivas: efeitos que se sobrepõem aos indivíduos que compõem a coletividade e que refletem a própria coletividade. As representações coletivas diferem das representações individuais, assim como a associação de seres humanos produz um todo que se sobrepõe às partes que o formam" (Durkheim, 1968).

O termo "senso comum" é utilizado por Schutz (1973) para abordar representações sociais. Para o autor, conjuntos de abstrações, formalizações e generalizações estão envolvidos tanto no conhecimento científico como no senso comum. Desta forma, o dia-a-dia, a existência cotidiana, é dotada de significados e traz estruturas importantes para os grupos sociais que vivem num contexto social determinado. Os cientistas sociais, por outro lado, selecionam esses significados através de construções mentais, representações do senso comum, para compor o seu objeto de estudo.

Ainda de acordo com o autor, a quantidade e o tipo de experiências de qualquer ator social dependem das experiências vividas pelo mesmo e, de acordo com seu trajeto de vida ele atribui relevância a temas, aspectos ou situações específicas. Assim, o senso comum é de fundamental importância. Através dele, o ator social define a situação de acordo com sua história de vida e seu estoque de conhecimentos, agindo e atribuindo significados à sua ação. $O$ estoque de conhecimentos é formado a partir das 
tipificações do mundo do senso comum, permitindo a identificação de grupos, estruturação de relevâncias e possibilidade de compreensão do modo de vida de um grupo.

Segundo Minayo (1992), Weber, no campo de representação social, elabora os termos como "idéias", espírito, concepções, mentalidade, usando-os como símbolos. Para Weber, a vida social, que consiste na conduta cotidiana do indivíduo, é carregada de significação cultural. Essa significação é dada tanto pela base material como pelas idéias, dentro de uma adequação, em que ambas se condicionam mutualmente.

Segundo Weber, as representações sociais são juízos de valor que o indivíduo dotado de vontade possui. Portanto, as concepções sobre o real têm uma dinâmica própria e podem apresentar tanta importância quanto a base material.

"Não são as idéias, mas os interesse materiais e ideais que governam diretamente a conduta do homem. Muito freqüentemente, porém, as "imagens mundiais", que foram criada pelas idéias, determinaram como manobreiros, as linhas ao longo das quais a ação foi impulsionada pela dinâmica dos interesses" (Weber, 1974, p.83) ${ }^{12}$.

Minayo (1992) identifica na dialética marxista a possibilidade de interpretação do papel das representações sociais, particularmente em "A ideologia alemã". Sob tal perspectiva, o modo de produção da vida material determina o modo de vida dos indivíduos como princípio básico do "pensamento" e da "consciência". Marx relativizaria, segundo Minayo (1992), este determinismo econômico sobre a consciência, reconhecendo que a manifestação da consciência se faz através da linguagem.

Gramsci aborda o tema, ao tratar do senso comum e do bom senso. Para Minayo (1992), a contribuição de Gramsci sobre as representações sociais é evidenciada

\footnotetext{
${ }^{12}$ Weber (1974, p.83) citado por Minayo (1992)
} 
em três aspectos fundamentais: o caráter de conformismo das representações e a abrangência desse conformismo de acordo com os diferentes grupos sociais, ou seja, cada grupo social tem seu próprio conformismo e ilusão; os aspectos dinâmicos geradores de mudanças que coexistem com o conservadorismo no senso comum; a composição mais abrangente das diferentes concepções do mundo de qualquer grupo social e de determinada época histórica.

Como tal, a leitura de Minayo (1992) sobre o conceito de representações sociais em Gramsci diz respeito a "uma combinação específica das idéias das classes dominantes e das concepções dos grupos subalternos, numa relação de dominação, subordinação e resistência entre os dois pólos" (Minayo 1992, p.169).

$\mathrm{Na}$ área da psicologia, Moscovici (1978) retoma a idéia de representação coletiva de Durkheim, definindo como: a reprodução das propriedades de um determinado objeto pelo homem não é o reflexo de uma realidade externa perfeitamente acabada, mas uma verdadeira construção mental do objeto, que implica reconstruí-lo dentro de um contexto de valores, noções e regras. A representação social é elaborada pela atividade simbólica do indivíduo que, assim, apreende o seu ambiente. Portanto, a representação social só pode ser compreendida se também for buscada a história individual relacionada à história da sociedade a qual o indivíduo pertence. Ela é o processo e o produto da relação entre a atividade mental e a práxis social. As pessoas agem concretamente no cotidiano, fazendo história, comunicando-se umas com as outras através de representações sociais que, por sua vez, são redefinidas. $O$ autor reconhece que a representação social é um conjunto de conceitos, explicações e afirmações que se originam na vida diária, no curso de comunicações interindividuais. $\mathrm{O}$ universo das representações sociais é o universo consensual, sendo que a linguagem desempenha um importante papel, facilitando associações de idéias, reconstruções de regras e valores, onde o desconhecido passa, simbolicamente, a conhecido.

Os dois processos básicos da representação social, segundo Moscovici (1978), são a ancoragem e a objetivação. Ancorar é trazer para categorias e imagens conhecidas o que não está ainda classificado e rotulado. É transformar o que é estranho em algo familiar, ou seja, ancorar o desconhecido em representações já existentes. 
Assim, o novo objeto da representação ganha sentido; o que é novidade passa a ser parte integrante e enraizada no sistema de pensamento oficial (ciência) ou em outras representações e, por sua vez, passa a fazer parte do sistema de integração entre o indivíduo e o mundo social, porque o que é comum ao grupo permite compartilhar comunicação e influenciar a ação. Objetivar é transformar uma abstração em algo quase físico. Objetivação é o processo através do qual se cristaliza uma representação: noções abstratas são transformadas em imagens cujo conteúdo interno após descontextualizar-se forma um núcleo figurativo para, por fim, transformar as imagens em elementos da realidade. Importante também é salientar que, para qualificar uma representação como social, é preciso definir o agente que a produz e enfatizar que a representação tem como função contribuir exclusivamente para os processos de formação de condutas e de orientação das comunicações sociais.

Spink (1994) acrescenta que:

"a elaboração das representações sociais, enquanto formas de conhecimentos práticos que orientam a ação, se dá na interface de duas forças monumentais. De um lado temos os conteúdos que circulam numa dada sociedade que têm suas origens tanto nas produções culturais mais remotas constituintes do imaginário social, quanto nas produções locais e atuais que emergem da convivência cotidiana. De outro lado temos as forças decorrentes do próprio processo de interação social e as pressões para definir uma dada situação de forma a confirmar e manter identidades coletivas".

Basicamente, pode-se dizer que a representação social é uma forma de produção e propagação do conhecimento que se constitui no mundo da vida do cotidiano. Em trabalhos publicados por autores especialistas nesse campo de estudo (como Moscovici, 1978; Mary Jane, 1994; Celso Sá, 1993; dentre vários outros), definem-se as representações sociais como um modelo de conhecimento específico, embasado no senso prático do saber comum, que tem como função estruturar 
comunicação, conhecimento, comportamento e práticas sociais.

Apesar dos inúmeros e frutíferos esforços realizados no estudo das representações sociais, Donnay e Charlie (1990, apud Silva 2000) sublinham que é uma ilusão pensar que é possível aprender todo o conteúdo da representação de um objeto. Segundo os autores, aprendemos apenas um aspecto fragmentário das representações que o sujeito queira nos comunicar. Os autores apresentam, ainda, que as representações variam não somente em função do objeto, da pessoa ou do grupo, mas também da situação de referência, do projeto na qual elas se inscrevem e do momento no qual elas são formuladas.

Tendo em vista todas estas abordagens, Minayo (1992, p.173) conclui:

"Podemos dizer que as representações sociais enquanto senso comum, idéias, imagens, concepções e visão do mundo que os atores sociais possuem sobre a realidade são um material importante para a pesquisa no interior das Ciências Sociais".

As reflexões a respeito de representação social levam a concluir que o ser humano, objeto e sujeito da história, desenvolve-se através de processo de comunicação, onde a representação social, dinamicamente, é estruturada. Portanto para analisar as representações que um indivíduo tem do meio ambiente, é necessário captar a visão que tem de seu mundo, sabendo que tal visão dependerá do lugar ocupado pelo indivíduo em relação aos outros. Esta relação não é apenas objetiva, mas também subjetiva, onde um se confronta com o outro e, ao mesmo tempo, com a imagem que elabora do outro. Por sua vez, ouvir o produtor familiar significa tentar compreender como seu espaço se constitui nesta relação enquanto realidade subjetiva que se insere no real. 


\subsection{Caracterização da área do estudo}

A região alvo da presente pesquisa é o Assentamento Sumaré II, criada pelo Decreto N. ${ }^{\circ} 99.144$ de 12-03-90 e complementada pelo Decreto N. 98.897 de 3001-91 que dispõe da nova concepção de unidade de conservação. $O$ assentamento localiza-se no Estado de São Paulo entre os municípios de Sumaré e Hortolândia, com um total de 70 hectares, basicamente formado por: de um lado, a agrovila ( 0,6 ha pertencente a cada família para construção da residência) e do outro lado, a área para produção com cinco hectares por família (denominado "roça" pela população local). É importante mencionar que, a partir do ano 2000, vinte e três (23) famílias foram beneficiadas com dois ou três hectares, fracionando assim, sua área em 3 partes (Informações obtidas através do técnico do Itesp, 2002).

Os dados obtidos no desenvolvimento deste trabalho mostram que o assentamento possui 245 habitantes, distribuídos em 56 famílias residindo no assentamento, mas apenas 27 têm o título de concessão de uso da terra. Dentro de cada área pertencente ao titular em geral moram também filhos, genros, netos e agregados.

\subsection{Definição do método e técnicas}

Ao iniciar a apresentação dos procedimentos metodológicos utilizados neste trabalho, pretende-se indicar os caminhos percorridos na elaboração geral deste estudo. Primeiramente, entende-se que a escolha de uma metodologia particular, no que concerne tanto a coleta quanto a análise de dados, está ligada a opções epistemológicas que fundamentam qualquer tipo de pesquisa. A escolha das práticas de pesquisa depende das questões que são feitas, que por sua vez dependem do contexto em que estão 
inseridas. Este estudo pretende trazer à tona particularidades da população estudada inscritas num momento específico desta coletividade, portanto devem ser reconhecidas como fenômenos psicossociais históricos e culturalmente condicionados. Sendo assim, esta pesquisa não pretende oferecer resultados replicáveis ou generalizáveis para outros contextos. Por ser histórico, este ou qualquer outro estudo de representação social, não oferece a possibilidade de busca de processos básicos e universais.

Na construção do objeto deste estudo, a metodologia utilizada sustentou-se em uma base diversificada e combinada entre si, onde entrevistas, observação participante de reuniões, festas populares e manifestações da vida social local possibilitaram abstrair, da vida diária, elementos importantes de teorização sobre o modo de vida no Assentamento Sumaré II. Buscou entender que tipos de relações estabelecem estes moradores com a natureza, como estruturam suas concepções e práticas.

Para os estudos da representação social, foram aplicados entrevistas e questionários para, posteriormente, construir um índice que mostrasse através da ação humana sua representação ecológica (denominado IREc - Índice de Representação ecológica), que tem como objetivo propor uma metodologia que possa expressar, de uma forma que melhor visualize o perfil ecológico do produtor familiar. Vale ressaltar que este índice, proposto neste trabalho, não deve ser visto como algo pronto $\mathrm{e}$ descontextualizado da realidade, mas sim uma forma de, em conjunto com as observações de campo junto à comunidade estudada, verificar e comparar o grau de representação ecológica dos entrevistados, servindo como indicador para futuras ações que poderão ser desenvolvidas dentro do assentamento.

Para o desenvolvimento deste trabalho a pesquisa de campo compreendeu três blocos de atividades:

1. A revisão bibliográfica foi utilizada como norteadora para 0 desenvolvimento e análise deste trabalho.

2. Utilizou-se entrevista semi-estruturada (com perguntas fechadas e abertas), fazendo um levantamento referente ao perfil sócioeconômico dos pequenos agricultores, relacionando com a formação do assentamento em estudo. Com a utilização do mesmo instrumento 
de pesquisa também se verificou a representação do produtor familiar com o meio ambiente no universo pesquisado. Na elaboração dos questionários da pesquisa de campo, contou-se com o auxílio de técnicos e lideranças com vivência na comunidade envolvida. Para tal fim, foi feito um censo dos moradores que tem o titulo de concessão do uso da terra, totalizando 27 famílias. A escolha dessas pessoas se deu devido o fato de serem os primeiros moradores o que possibilitou um maior detalhamento das informações requeridas pela pesquisa. Com isso, através do censo das famílias, obteve-se a atualização dos dados referentes ao total de habitantes do local estudado, números de famílias e algumas de suas características, tais como idade, sexo, escolaridade, etc. Outro objetivo alcançado foi um maior conhecimento do tipo e modo de produção agrícola do local. Partindo-se da premissa que não havia informações acerca das variáveis envolvidas, delimitou-se, inicialmente, $10 \%$ da população objeto como amostra piloto. Algumas modificações e acréscimos foram realizados depois deste primeiro contato, contribuindo para a melhor elaboração do questionário que foi enfim aplicado.

3. Para a análise dos dados coletados, foram seguidos os seguintes passos:

- Tabulação e análise dos dados: foi feita utilizando-se os softwares disponíveis para este fim (SPSS 10.0 for Windows, Microsoft Excel e MINITAB).

- Análise estatística do material coletado: as técnicas estatísticas utilizadas neste trabalho são descritivas tendo em vista que foi pesquisada a população, não havendo, portanto, qualquer erro amostral. $\mathrm{Na}$ análise das questões abertas, buscou-se o agrupamento das respostas tendo como objetivo adaptá-las às técnicas estatísticas. Onde isto não foi possível, foram utilizadas análises críticas sobre os assuntos abordados. Assim, não foi necessária a utilização de 
ferramentas mais sofisticadas de análise estatística.

Através da análise descritiva dos dados referentes ao universo pesquisado, com a obtenção de alguns parâmetros populacionais referentes à situação social e econômica foi possível traçar o perfil dos assentados. A utilização de gráficos e tabelas, visou facilitar a visualização das informações obtidas.

Uma das finalidades e propósito central da pesquisa realizada junto aos moradores do assentamento Sumaré II foi verificar a representação ecológica, através das ações do produtor com relação ao meio ambiente. Com este fim, foram utilizadas algumas perguntas do questionário, cujo conteúdo se mostrou adequado para identificar, e eventualmente medir o nível de representação ecológica dos entrevistados e, a partir delas, buscou-se construir um índice, denominado Índice de Representação Ecológica (IREc). Das perguntas relacionadas no questionário, doze (12) delas tinham relação com a ação humana sobre o meio ambiente e foram, inicialmente, selecionadas para o estabelecimento do IREc. Com o advento das respostas, percebeu-se que a pergunta relacionada à agricultura orgânica não era passível de ser utilizada devido ao desconhecimento (e mesmo a dificuldade de conceituar), pela maior parte dos agricultores, do que é a agricultura orgânica. Este motivo, associado às dificuldades existentes na utilização da agricultura orgânica em plantios e na obtenção de certificação para os produtos, fez com que uma das perguntas fosse desprezada. Assim, onze (11) questões foram utilizadas realmente para o estabelecimento do IREc.

Utilizaram-se, para obtenção do IREc, juízes, que deram notas a quesitos dentro das questões apresentadas. Foram escolhidos cinco juízes, tendo como critério aliar a prática à teoria. Assim, um dos juízes é um morador do assentamento, que vivencia os problemas em seu dia-a-dia e toma decisões baseadas na realidade vivida dentro do assentamento. Por ser um participante do processo e, ao mesmo tempo, agente ativo e passivo, pode oferecer uma visão de dentro para fora do assentamento. Dois outros juízes são professores da UNICAMP, com larga experiência acadêmica em contato com a problemática rural e com vivência dentro do Assentamento objeto do estudo, servindo assim de elo entre o teórico e o prático vivencial. Por fim, foram escolhidos dois juízes que são professores da ESALQ/USP, também com formação 
teórica sólida e com vivência em outros locais, permitindo assim obter dados com outro referencial. Com este procedimento metodológico, evitou-se o viés que ocorreria caso o pesquisador envolvido diretamente no trabalho fizesse todo julgamento sozinho. Relativizou-se, assim, a arbitrariedade do pesquisador. É necessário mencionar que existe um viés de cada um dos juízes, seja pelo referencial teórico característico de cada um deles como também pela vivência dos mesmos. Entretanto, a utilização das médias das notas dos juízes para a classificação dos assentados em classes faz com que haja uma diluição e uma anulação deste viés. Assim, antes de proceder à análise propriamente dita, efetuou-se uma discussão referente às notas dos juízes, utilizando-se tanto a análise de variância quanto a análise de cluster para verificar diferenças entre as notas emitidas pelos diversos juízes, o que possibilitou ter uma visão mais ampla em relação às ambigüidades e disparidades de opiniões entre os mesmos, buscando assim verificar a validade do instrumento de análise utilizado para atingir a finalidade proposta.

Deve-se ter em mente que o índice estabelecido não serve para comparações entre assentamentos e sim para melhor visualizar a situação interna, podendo ser utilizado, de forma cuidadosa, para classificar os moradores em classes de representação ecológica. Comparações com outros assentamentos ou com reservas extrativistas ou ainda com outras formas de ocupação da terra só poderiam ser feitas se aplicados os questionários a estes locais, levando-se em conta ainda as diversidades existentes nos mesmos. Os procedimentos para a construção do IREc seguiram os seguintes passos:

a) escolha das questões: dentre as questões do questionário, onze delas foram escolhidas como questões de representação com o meio ambiente. Estão aí situadas as questões relativas ao uso de agrotóxico, destinação de embalagens, participação e motivação em mutirões, participação e motivação em reuniões de assentados, opiniões sobre desmate, sistemas agro-florestais (SAF) e sistemas de produção que levam em conta o meio-ambiente (Apêndice 3).

b) Utilização das respostas: as questões formuladas eram de três tipos: alternativas fechadas (uma única opção de escolha), questões de 
múltipla escolha (em que mais de uma alternativa poderia ser escolhida) e questões abertas. Neste último caso, foram utilizadas palavras-chave, com o objetivo de realizar o agrupamento destas questões em quesitos, para que pudessem ser avaliados objetivamente. Este procedimento foi possível devido a similaridade entre as respostas. Para melhor ilustrar este procedimento toma-se como exemplo a pergunta $n^{0} 4$ do questionário aplicado: Por quê você participa nos mutirões para o plantio de árvores dentro do assentamento?. Algumas das respostas obtidas foram: A- árvore é importante para meio ambiente, B- conservar o meio ambiente; $\mathrm{C}$ plantando árvores estou fazendo bem ao meio ambiente. Desta forma, construiu-se, para esta questão o quesito "Preocupação com o meio ambiente". E assim, para cada questão foram elaboradas as alternativas de resposta dada pelos pesquisados.

c) Numa segunda etapa, foram convidados cinco juízes para emitirem notas, que variavam de -5 a 5 , para cada um dos quesitos de cada questão. Os casos em que os pesquisadores se recusaram a dar notas a alguns quesitos por não ter conhecimento aprofundado sobre o assunto, considerou-se como dados perdidos.

d) $\mathrm{Na}$ terceira etapa, buscou-se a construção do $I R E c_{j}$ baseado nas notas de cada juiz $j$, calculando-se, para cada família de assentado, um índice a partir da média das notas dadas a cada item. Observou-se que as questões 1 e 2 (P1 e P2) referiam-se à participação em eventos voltados ao meio-ambiente dentro do assentamento, sendo a primeira referente à participação em si e a segunda ao motivo da participação. Uma cópia do questionário encontra-se no Apêndice 1. Assim, estas duas questões foram unidas em uma única $\left(P 1_{-} 2_{j}\right)$, através da média ponderada das notas dadas pelo juiz $j$, considerando-se o peso 1 para a participação e peso 2 para o motivo. A mesma metodologia foi utilizada para as questões 3 e 4 (P3 e P4), referentes à participação em 
mutirões para o plantio de árvores dentro do assentamento, que originou a $P 34_{j}$. Assim, calculou-se o $I R E c_{j}$ para uma dada família $i$ da seguinte maneira:

$$
\begin{aligned}
I R E c_{i j}=\frac{1}{9}\left[P 1_{-} 2_{i j}+P 3_{-} 4_{i j}+\right. & P 5_{i j}+P 7_{i j}+P 8_{i j}+ \\
& \left.+P 9_{i j}+P 10_{i j}+P 11_{i j}+P 12_{i j}\right]
\end{aligned}
$$

onde

$\mathrm{P} 1 \_2 \mathrm{ij}$ : média ponderada das notas dadas pelo juiz $\mathrm{j}$ para os quesitos 1 e 2 para a família $i$;

P3_ $4_{i j}$ : média ponderada das notas dadas pelo juiz $\mathrm{j}$ para os quesitos 3 e 4 para a família $i$;

$P k_{\mathrm{jj}}$ : nota dada pelo juiz $\mathrm{j}$ na questão $\mathrm{k}$ para a família $\mathrm{i}$.

Observa-se ainda que, em algumas questões, as respostas poderiam ser dadas em vários quesitos. Nestes casos, como havia uma nota do juiz para cada quesito, calculou-se uma média aritmética destas notas e obteve-se assim um único valor para a questão baseado nesta média.

Desta forma, o IREc para a família $i$ foi obtido pela média aritmética dos índices referentes a cada um dos juízes, ou seja,

$$
I R E c_{i}=\frac{1}{5} \sum_{j=1}^{5} I R E c_{j}=\frac{I R E c_{1}+I R E c_{2}+I R E c_{3}+I R E c_{4}+I R E c_{5}}{5}
$$

A partir dos resultados destes índices, cada família foi classificada de acordo com seu posto (rank), ou seja, a família com o menor índice obteve o posto 1 , com o segundo menor índice o posto $2 \mathrm{e}$ assim sucessivamente.

Finalmente, considerou-se uma divisão das famílias dos assentados em três (3) grupos, de acordo com a ordem crescente dos índices calculados: menor, média e maior representação ecológica para verificar o grau de percepção da importância do meio ambiente em suas atividade. Para realizar tal divisão considerou-se o índice de menor valor $\left(I_{\min }\right)$ e o de maior valor $\left(I_{\max }\right)$, obtendo o ponto de corte superior $L S_{g}$ do grupo $g$ da seguinte forma: 


$$
L S_{g}=I_{\min }+\frac{g \times\left(I_{\max }-I_{\min }\right)}{3}
$$

Obviamente, o ponto de corte superior da última classe é igual ao índice de maior valor. Os limites inferiores e superiores para a formação dos grupos são apresentados na tabela 1.

Tabela 1. Limites inferiores e superiores dos grupos.

\begin{tabular}{ccc}
\hline $\begin{array}{c}\text { Grupos de Representação } \\
\text { Ecológica }\end{array}$ & Limite Inferior & Limite Superior \\
\hline MENOR & & \\
MÉDIA & $I_{\min }+\left(I_{\max }-I_{\min }\right) / 3$ & $I_{\min }+2 \times\left(I_{\max }-I_{\min }\right) / 3$ \\
MAIOR & $I_{\min }+2 \times\left(I_{\max }-I_{\min }\right) / 3$ & $I_{\max }$ \\
\hline
\end{tabular}

\subsection{Fonte dos dados}

A fonte básica de dados usados para o desenvolvimento do presente trabalho é oriunda de uma pesquisa de campo que foi realizado junto à comunidade local.

Além da fonte principal, realizou-se coleta de dados secundários junto à Associação dos Pequenos Produtores da região de Sumaré, Secretarias de Estado do Governo e ITESP ${ }^{13}$.

Outras fontes importantes de informações para o alcance dos objetivos do trabalho foram entrevistas não-estruturadas (informais) com pequenos produtores rurais residentes na área estudada e com pessoas que desenvolvem trabalhos com a população local. Nestas entrevistas, utilizou-se apenas um roteiro, sem perguntas fechadas, com possibilidade do entrevistador, dependendo das respostas, discorrer mais longamente sobre o tema proposto, incluindo informações de diversas natureza.

\footnotetext{
${ }^{13}$ A Fundação Instituto de Terras do Estado de São Paulo "José Gomes da Silva" - Itesp - vinculada à Secretaria da Justiça e da Defesa da Cidadania, foi criada pela lei $n^{\circ} 10.207$, de 8 de janeiro de 1999, e regulamentada pelo Decreto $n^{\circ} 44.294$, de 4 de outubro de 1999, tendo por objetivo planejar e executar as politicas agrárias e fundiárias no âmbito do Estado.
} 


\section{RESULTADOS E DISCUSSÃo}

$O$ instrumento utilizado para a obtenção dos dados com a finalidade de compreender a realidade estudada foi o questionário (Anexo 1). A maior parte da pesquisa de campo restringiu-se ao assentado possuidor do título da posse de terra no Assentamento Sumaré II. Esta escolha teve como motivação principal o fato dele estar envolvido diretamente no uso do solo através de suas práticas agrícolas, além dele ser, dentro do lote, o morador mais antigo. Assim, através dele, direta ou indiretamente, foi possível obter maiores informações relacionadas aos objetivos deste trabalho.

Os dados obtidos podem ser classificados em três (3) grupos principais de informações:

1. Perfil dos produtores familiar do Sumaré II;

2. Relação com a natureza;

3. Representação ecológica dos produtores familiares do Sumaré II.

\subsection{Perfil do produtor familiar do Sumaré II}

O objetivo desta parte do trabalho é apresentar de maneira descritiva alguns elementos que compõem o perfil social e econômico do produtor familiar de Sumaré II.

\subsubsection{Perfil social do produtor familiar}

No perfil social, obtiveram-se informações relacionadas a moradia, idade, sexo, estado civil, relação de parentesco com o responsável pelo lote, religião, qualidade de vida, origem, tempo que reside no assentamento e atividade desenvolvida pelo responsável pelo lote antes de residir no assentamento. 


\section{a. Moradia Principal}

Muitos problemas ainda a população do Sumaré II enfrenta. Pode-se dizer que o problema de água ainda é um entrave para o desenvolvimento local. A cada ano, no período da seca, a falta d'água chega a comprometer a irrigação. Uma solução encontrada foi a construção, em cada lote familiar, de poços cacimba, mas que não pode ser considerado como fonte permanente de abastecimento d'água, já que no verão há muita escassez. A construção de fossas sépticas solucionou o problema do esgoto. $O$ fornecimento de energia elétrica, dada a proximidade urbana, serve aos dois assentamentos sem grandes problemas.

Todas as moradias (27) são de tijolo ou bloco, 22 casas têm cobertura de telha de amianto enquanto as restantes são cobertas por telhas de cerâmica. Em relação ao piso, 15 delas têm piso frio e 12 são cimentados. Todas as moradias têm iluminação elétrica, mas não têm saneamento básico fornecido por instituição pública, utilizando fossas. Em relação ao fornecimento de água, cada casa possui um poço semi-artesiano para consumo próprio. Na área de cultivo é utilizado um poço artesiano comunitário e também a água retirada do Rio Quilombo através de bombas de irrigação. Além disso, em 16 das 27 casas, a água para beber é tratada (filtrada ou com cloro).

Apenas quatro das 27 casas não possuem nenhum tipo de telefone, 12 possuem telefone convencional, 4 telefones celulares e 7 possuem os dois tipos de telefone. Todas as casas possuem fogão a gás.

Tabela 2. Número de cômodos nas casas principais dos lotes.

\begin{tabular}{lr}
\hline Número de Cômodos & $\mathrm{N}^{0}$ de Casas \\
\hline 4 & 2 \\
5 & 8 \\
6 & 7 \\
7 & 1 \\
8 & 2 \\
9 & 4 \\
10 & 2 \\
Não informado & 1 \\
Total & 27 \\
\hline
\end{tabular}


Dez casas possuem ainda fogão a lenha para a utilização em cozimentos mais demorados tais como confecção de doces para venda, etc.

Quanto ao número de cômodos da casa principal do lote, eles variam de 4 a 10, sendo que a maior parte das casas têm 5 ou 6 cômodos (ver tabela 2).

$\mathrm{O}$ número de casas por lote encontra-se na tabela 3 . Verifica-se que em vinte lotes foram encontradas duas casas ou mais, significando que, para agregar familiares ou outros, o titular cede uma parte de sua área para construção de moradia para abrigá-los e em alguns casos compartilham também a área de produção.

Tabela 3. Número de casas por lote.

\begin{tabular}{rr}
\hline Número de Casas & $\mathrm{N}^{\circ}$ de Lotes \\
\hline 1 & 7 \\
2 & 12 \\
3 & 6 \\
4 & 2 \\
\hline
\end{tabular}

\section{b. Idade}

A idade média dos assentados foi de 27,9 anos e desvio padrão 20,2 anos, sendo que a idade máxima foi de 81 anos. A distribuição das idades é parecida com o padrão brasileiro em geral, com um número grande de crianças menores com 10 anos ou menos (24,1\%). Além disso, cerca de 9,4\% dos assentados têm mais de 60 anos. Quase metade da população local tem idade entre 16 e 40 anos.

Tabela 4. Idade da população do Assentamento Sumaré II.

\begin{tabular}{rcrr}
\hline Classes de Idade & Frequência & $\%$ & $\%$ Acumulado \\
\hline 0 a 10 & 59 & 24,1 & 24,1 \\
11 a 15 & 22 & 9,0 & 33,1 \\
16 a 20 & 19 & 7,8 & 40,8 \\
21 a 30 & 54 & 22,0 & 62,9 \\
31 a 40 & 39 & 15,9 & 78,8 \\
41 a 60 & 29 & 11,8 & 90,6 \\
> 60 & 23 & 9,4 & 100,0 \\
Total & 245 & 100,0 & \\
\hline
\end{tabular}


c. Sexo

Do total de 235 moradores do assentamento, $110(44,9 \%)$ são do sexo feminino e $135(55,1 \%)$ do sexo masculino. Entretanto, a distribuição, por faixa etária, mostra que há mais mulheres do que homens na faixa etária acima de 50 anos e igualdade na faixa de 41 a 50 anos. Em todas as outras faixas etárias, há predominância do número de homens. Os percentuais da tabela 5 foram obtidos dentro de cada faixa etária. Assim, por exemplo, para crianças até 5 anos, 41 \% são do sexo feminino e 59\% do sexo masculino.

Tabela 5 . Faixa etária por sexo da população do Assentamento Sumaré II.

\begin{tabular}{cccccc}
\hline Faixas & Feminino & \multicolumn{2}{c}{ Masculino } & Total por faixa \\
Etárias & Frequência & $\%$ & Frequência & $\%$ & Etária \\
\hline 0 a 5 & 13 & 41 & 19 & 59 & 32 \\
6 a 10 & 10 & 37 & 17 & 63 & 27 \\
11 a 15 & 10 & 45 & 12 & 55 & 22 \\
16 a 20 & 9 & 47 & 10 & 53 & 19 \\
21 a 30 & 26 & 48 & 28 & 52 & 54 \\
31 a 40 & 15 & 38 & 24 & 62 & 39 \\
41 a 50 & 8 & 50 & 8 & 50 & 16 \\
> 50 & 19 & 53 & 17 & 47 & 36 \\
0 & 110 & 45 & 135 & 55 & 245 \\
\hline
\end{tabular}

\section{d. Estado Civil}

Dos moradores com idade maior ou igual 16 anos, 47\% são casados. Considerando ainda os que se declararam amigados, $61 \%$ dos moradores mantêm uma relação estável, conforme a tabela 6 .

Tabela 6. Estado civil da população do Assentamento Sumaré II.

\begin{tabular}{lrrr}
\hline ESTADO CIVIL & Frequência & $\%$ & \% Válidos \\
\hline Casado & 77 & 31,4 & 47,0 \\
Solteiro & 53 & 21,6 & 32,3 \\
Amigado & 23 & 9,4 & 14,0 \\
Viúvo & 8 & 3,3 & 4,9 \\
Separado & 3 & 1,2 & 1,8 \\
Sub-total & 164 & 66,9 & 100,0 \\
<16 anos & 81 & 33,1 & \\
Total & 245 & 100,0 & \\
\hline
\end{tabular}


Para melhor ilustrar a situação referente ao estado civil dos assentados, a tabela 7 mostra a distribuição dos moradores pela faixa etária.

Tabela 7. Distribuição do estado civil da população por faixa etária.

\begin{tabular}{|c|c|c|c|c|c|c|c|c|}
\hline \multirow[t]{2}{*}{$\overline{\text { Estado Civil }}$} & \multicolumn{7}{|c|}{ Faixas Etárias } & \multirow[b]{2}{*}{ Total } \\
\hline & 0 a 10 & 11 a 15 & 16 a 20 & 21 a 30 & 31 a 40 & 41 a 60 & $>60$ & \\
\hline$\overline{\text { Amigado }}$ & 0 & 0 & 0 & 10 & 11 & 2 & 0 & $\overline{23}$ \\
\hline Casado & 0 & 0 & 1 & 18 & 21 & 21 & 16 & 77 \\
\hline Separado & 0 & 0 & 0 & 1 & 0 & 2 & 0 & \\
\hline Solteiro & 59 & 22 & 18 & 25 & 6 & 4 & 0 & 134 \\
\hline Viúvo & 0 & 0 & 0 & 0 & 1 & 0 & 7 & 8 \\
\hline Total & 59 & 22 & 19 & 54 & 39 & 29 & 23 & 245 \\
\hline
\end{tabular}

\section{e. Relação de parentesco com o responsável pelo lote}

A relação com o responsável pelo lote pode ser verificada na tabela 8 . Para o cálculo dos percentuais foram considerados apenas 218 moradores, ou seja, foram retirados do cálculo os 27 responsáveis pelos lotes. Assim, dos 218 restantes tem-se que $33 \%$ são filhos ou filhas dos responsáveis, $11 \%$ são cônjuges e $54,6 \%$ têm algum outro tipo de parentesco (cunhadas (os), tios (as), sobrinhas (os), genros e/ou noras, etc.). Por outro lado, 1,4\% dos moradores não apresentam nenhuma relação de parentesco, sendo neste trabalho denominados agregados.

Tabela 8. Relação de parentesco com o responsável pelo lote.

\begin{tabular}{lrr}
\hline Relação de Parentesco & Frequência & $\%$ \\
\hline Agregado & 3 & 1,4 \\
Cônjuge & 24 & 11,0 \\
Filho(a) & 72 & 33,0 \\
Outro parentesco & 119 & 54,6 \\
Total & 218 & 100,0 \\
\hline
\end{tabular}

\section{e. Religião}

Predomina, dentro do assentamento, a religião católica $(63,3 \%)$ seguida da evangélica $(24,1 \%)$. 
Tabela 9. Religião declarada.

\begin{tabular}{lrr}
\hline Religião Declarada & Frequência & $\%$ \\
\hline Católica & 155 & 63,3 \\
Evangelista & 59 & 24,1 \\
Outras & 31 & 12,7 \\
Total & 245 & 100,0 \\
\hline
\end{tabular}

\section{f. Qualidade de vida}

Nas entrevistas realizadas junto aos assentados, ao perguntar sobre sua trajetória de vida, antes e depois do assentamento, 88,9\% disseram que depois que vieram morar no assentamento teve um aumento na qualidade de vida, conforme mostra a tabela 10. Por outro lado, nenhum dos assentados declarou que sua situação atual é pior que aquela anterior à sua vinda ao assentamento.

Tabela10. Situação atual em relação à situação antes de vir para o assentamento.

\begin{tabular}{lrr}
\hline Situação Atual & Frequência & $\%$ \\
\hline Melhorou & 24 & 88,9 \\
Não modificou & 3 & 11,1 \\
Piorou & 0 & 0,0 \\
Total & 27 & 100,0 \\
\hline
\end{tabular}

\section{g. Origem}

Ao perguntar ao titular onde residia antes de vir para o assentamento, corroborando com alguns estudos já realizado anteriormente sobre o assunto, mostra que a população local é oriunda, sua maioria, da região de Campinas.

Tabela 11. Cidade onde residia o titular antes de vir para o assentamento.

\begin{tabular}{lrr}
\hline Cidade onde Residia & Frequência & $\%$ \\
\hline Campinas & 3 & 11,1 \\
Hortolândia & 4 & 14,8 \\
Nova Odessa & 1 & 3,7 \\
Oroeste & 1 & 3,7 \\
Sumaré & 15 & 55,6 \\
Valinhos & 3 & 11,1 \\
Total & 27 & 100,0 \\
\hline
\end{tabular}




\section{h. Tempo que reside no assentamento}

A maior parte dos assentados (63\%) residem no local a 17 anos. Estes formaram o núcleo criador do assentamento Sumaré ПI. Os outros moradores foram agregados no decorrer do tempo.

Tabela 12. Tempo que a família reside no assentamento.

\begin{tabular}{crr}
\hline $\begin{array}{c}\text { Tempo no Assentamento } \\
\text { (em anos) }\end{array}$ & Frequência & $\%$ \\
\hline 3 & 1 & 3,7 \\
4 & 1 & 3,7 \\
5 & 1 & 3,7 \\
6 & 1 & 3,7 \\
8 & 4 & 14,8 \\
12 & 1 & 3,7 \\
15 & 1 & 3,7 \\
17 & 17 & 63,0 \\
Total & 27 & 100,0 \\
\hline
\end{tabular}

\section{i. Atividade anterior do titular (antes de residir no assentamento)}

A tabela 13 mostra que a agricultura era a atividade predominante dos assentados antes de morar no assentamento. Entretanto percebe-se um êxodo da cidade na busca de formas de sustento na zona rural, fugindo do desemprego ocorrido na década de 80 , sendo comum a presença de trabalhadores da construção civil, indústria e serviços.

Tabela 13. Atividade anterior do titular antes de residir no assentamento.

\begin{tabular}{lrr}
\hline Atividade Anterior & Frequência & $\%$ \\
\hline Agricultura & 10 & 37,0 \\
Construção Civil & 5 & 18,6 \\
Indústria & 4 & 14,8 \\
Serviços (Comércio, Cozinheiro, Balconista, Vendedor) & 4 & 14,8 \\
Outros (Aposentado, Estudante, Funcionário Público, & & \\
$\quad$ Seminarista) & 4 & 14,8 \\
Total & 27 & 100,0 \\
\hline
\end{tabular}

Pela tabela 13 percebe-se que $63 \%$ dos entrevistados exerciam atividades 
diferentes da atividade agrícola antes de vir para o assentamento. Esta mistura de pessoas com qualificações diferentes no assentamento tem origem na falta de perspectivas nos centros urbanos da região, gerada pelo desemprego e pelos baixos salários.

\subsubsection{Perfil econômico do produtor familiar}

O objetivo geral do perfil econômico do produtor familiar do assentamento Sumaré II, aqui proposto, é apresentar alguns aspectos econômicos obtidos através da pesquisa de campo. São eles: sistema de produção e força de trabalho não residente no lote

\section{a. Sistema de produção}

Existem 27 produtores no Assentamento Sumaré II, dos quais aproximadamente $63 \%$ utilizam a agricultura convenciona ${ }^{14} \mathrm{em}$ suas áreas de plantio e $37 \%$ em processo de transição. ${ }^{15}$

Durante o desenvolvimento da pesquisa foi verificado que, praticamente, todos produtores produzem um pouco de frutas e hortaliças em sua área de moradia para consumo doméstico. A produção inclui banana, laranja, limão, carambola, mandioca, batata-doce, repolho, couve, alface e tomate. Por outro lado, a mesma área serve para o cultivo de alguns produtos visando a comercialização. Tais produtos, os respectivos valores obtidos com a produção e os percentuais deste em relação ao ganho total obtido no ano agrícola de 2001 estão reproduzidos na Tabela 14.

Além dos produtos apresentados na tabela referida, são cultivados o arroz, o café e o feijão, que servem apenas para o consumo próprio, sem valor de comercialização. Quando contabilizados os valores obtidos com produtos de origem animal, destaca-se a criação de frangos, porcos, vacas e, especialmente, a comercialização de leite, que gerou $7,5 \%$ da renda bruta do assentamento.

\footnotetext{
${ }^{14}$ Agricultura convencional: sistema agrícola que utiliza pacote tecnológico (química) na lavoura ou criação.

${ }^{15}$ Processo de transição: transformação gradual de agricultura tradicional em agricultura orgânica
} 
Tabela 14. Valor obtido pela venda da produção e percentual em relação ao total anual.

\begin{tabular}{lrr}
\hline PRODUTO & Valor Obtido (em R\$) & $\%$ \\
\hline Abobrinha & 4218,00 & 1,7 \\
Acerola & 18800,00 & 7,8 \\
Banana & 1330,00 & 0,6 \\
Berinjela & 400,00 & 0,2 \\
Brócolis & 3350,00 & 1,4 \\
Brócolis ninja & 1000,00 & 0,4 \\
Couve-flor & 2200,00 & 0,9 \\
feijão de corda & 1290,00 & 0,5 \\
Folha de mandioca & 1800,00 & 0,7 \\
Frango & 5000,00 & 2,1 \\
Fruta pão & 50,00 & 0,0 \\
Jiló & 1400,00 & 0,6 \\
Goiaba & 114220,00 & 47,4 \\
Hortaliças & 6720,00 & 2,8 \\
Jaca & 900,00 & 0,4 \\
Leite & 18000,00 & 7,5 \\
Limão & 364,00 & 0,2 \\
Mamão & 60,00 & 0,0 \\
Mandioca & 29199,00 & 12,1 \\
Manga & 650,00 & 0,3 \\
Maracujá & 3040,00 & 1,3 \\
Milho seco & 300,00 & 0,1 \\
Milho verde & 8550,00 & 3,5 \\
Pimentão & 960,00 & 0,4 \\
Tangerina ponkan & 1500,00 & 0,6 \\
Porco & 3900,00 & 1,6 \\
Quiabo & 10830,00 & 4,5 \\
Vacas & 1000,00 & 0,4 \\
Total & 241031,00 & 100,0 \\
\hline & &
\end{tabular}

Um pequeno grupo de produtores vem tentando, já a algum tempo (aproximadamente 2 anos), um sistema de produção que busca manejar de forma equilibrada o solo e demais recursos naturais (água, plantas, animais, insetos, etc.). Este sistema de produção recebe o nome de cultivo orgânico pela população local. Contudo, pelo fato dos produtos por não ter certificação e por estar recebendo contaminação de produtos químicos de áreas vizinhas, este tipo de cultivo recebe, neste trabalho, a nomenclatura de semi-orgânico.

Após estudo no local, observa-se que, conforme a figura 01, a maior parte 
da população optou por modo de produção convencional por acreditarem que ainda é a única forma de produzir para seu sustento e de sua família. Um percentual pequeno da população utiliza-se do cultivo semi-orgânico, mas este vem crescendo e aos poucos se instalando no modo de produção local, apesar da carência orientação técnica.

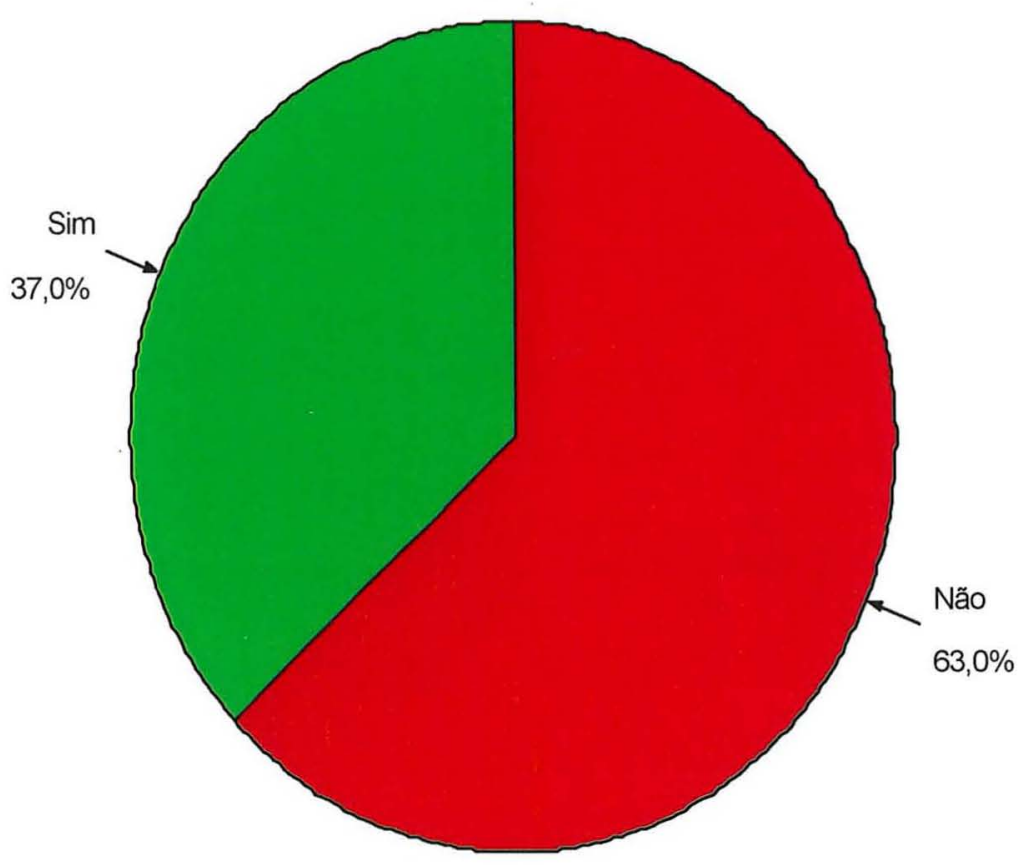

Figura 1 - Plantação semi-orgânica.

Dentre os produtos semi-orgânicos cultivados dentro do assentamento encontram-se a mandioca, o quiabo, o arroz, o feijão, a batata-doce, o chuchu, a acerola, o milho verde e a pimenta.

É importante observar que ao perguntar, à população estudada, o que conhecia sobre cultivo orgânico foi obtido como respostas os seguintes dados:

- $37 \%$ dos moradores têm em sua roça produtos semi-orgânicos e $63 \%$ não; 
- dos que têm em sua roça produtos semi-orgânicos, 10,0\% não conhece e 90,0\% responderam que é produção que não utiliza produtos químicos na lavoura, representando, respectivamente, 3,7 e $33,3 \%$ do total das famílias residentes no assentamento;

- dos que não cultivam produtos semi orgânicos $52,9 \%$ não responderam, $11,8 \%$ não conhecem, $5,9 \%$ disseram que é um tipo de agricultura sustentável, 5,9\% responderam que é um tipo de agricultura que só é viável em terra nova e ainda $23,5 \%$ disseram que é um tipo de agricultura que não usa química; estes percentuais equivalem, respectivamente, a $33,3 \%, 7,4 \%, 3,7 \%, 3,7 \%$ e $14,8 \%$, quando se consideram todos as 27 famílias do assentamento.

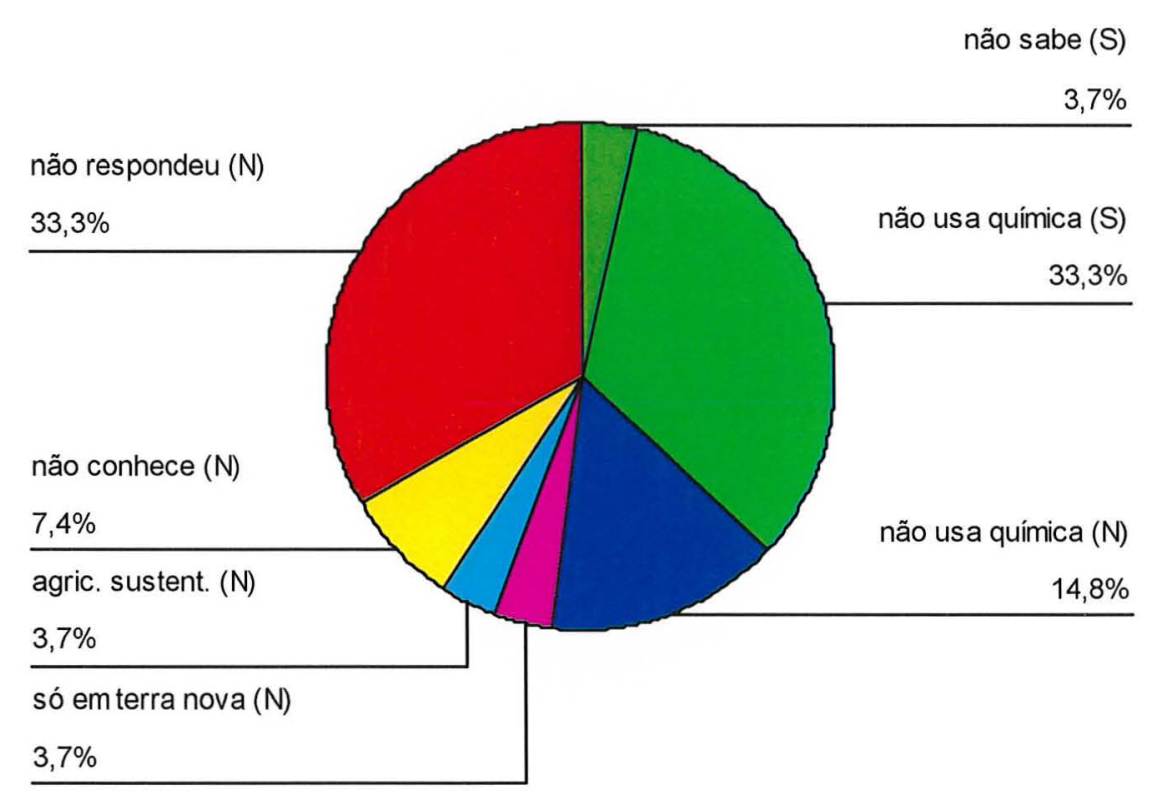

Figura 2 - Produtos orgânicos: definição.

Nas observações de campo foi constatado que a maioria dos moradores do assentamento têm noção do que sejam produtos orgânicos e sua importância para o meio ambiente e saúde do produtor e consumidor. Essa afirmativa é corroborada com o 
seguinte depoimento de um morador do assentamento Sumaré II: "No momento produtos químicos é a única solução para a produção para nós, pequenos produtores, sobreviver. Sei que não é bom para a terra e para a saúde de quem planta e come". Outro morador, ao falar sobre agricultura orgânica diz o seguinte: "sei dos perigos $d a$ agricultura convencional, mas não temos como plantar orgânicos; se eu não usar veneno na minha produção, o meu vizinho usa e acaba vindo para a minha plantação e, sendo assim, jamais vou conseguir a certificação dos meus produtos. Se não tem jeito, acabo optando pela agricultura convencional."

b. Força de trabalho não residente no lote (FTNRNL)

Ao verificar se a produção familiar empregava força de trabalho não residente no lote, foi constatado que $33,3 \%$ da famílias empregavam trabalhos temporários de terceiros para auxiliar na produção, enquanto $66,7 \%$ não utilizavam .

\subsection{Relação com a natureza}

\subsubsection{Sistema AgroFlorestal (SAF) como prática alternativa da atividade agrícola}

Há mais de um ano, um pequeno grupo de produtores do assentamento Sumaré II vem divulgando o sistema agroflorestal (Saf) como uma alternativa para substituir modo de produção convencional. Segundo a Cida (2001), moradora local: "O Saf irá contribuir para melhorar a qualidade de vida dos produtores; aumentaria a renda já que diminuiria os gastos com a produção, além disso, ao implantar o turismo rural no assentamento, os visitantes teriam oportunidade de conhecer o que é Sistemas Agroflorestais".

Com a finalidade de buscar saber qual é o grau de conhecimento do assentado em relação ao Saf e sua aceitação em relação a este sistema de plantio no questionário aplicado, foram feitas perguntas referente este tema, cujos resultados estão na tabela 17.

Do total dos entrevistados, $44,4 \%$ disseram que vale a pena implantar 
Safs em sua área de produção. Constatou-se ainda que $37 \%$ não conhecem o que vem a ser sistemas agroflorestais. Estes representam $67 \%$ dos que responderam pela não implantação do Safs em suas áreas. Vale apenas observar que, dos que responderam pela não implantação do Safs e que alegaram conhecer essa sistema de plantio, $80 \%$ deram como motivo a necessidade da utilização de parte da terra para agricultura convencional, já que nesta o retorno de produção é mais rápido, principalmente quando se possui uma pequena extensão de terra.

Tabela 15. Respostas relativas à implantação do Safs.

\begin{tabular}{lrr}
\hline Respostas & Frequência & $\%$ \\
\hline Sim & 12 & 44,44 \\
Não & & \\
$\quad$ Conhece & 5 & 18,6 \\
$\quad$ Desconhece & 10 & 37,0 \\
Total & 27 & 100,00 \\
\hline
\end{tabular}

\subsubsection{A função protetora da mata ciliar no Sumaré II}

As informações nesta fase da pesquisa foram obtidas através de perguntas informais junto aos entrevistados e também em observação de campo.

A importância da preservação ou restauração das florestas ao longo do rio Quilombo e do ribeirão Jacumbá, presentes no assentamento Sumaré II, fundamenta-se no amplo espectro de benefícios que este tipo de vegetação traz ao ecossistema local, exercendo função protetora sobre os recursos naturais bióticos e abióticos.

Do ponto de vista dos recursos bióticos, segundo os moradores locais, estas matas, estendendo-se como uma faixa de vegetação, criam condições favoráveis para a sobrevivência e manutenção do fluxo gênico entre populações de espécies animais que habitam as faixas ciliares, ou mesmo fragmentos florestais maiores por elas conectados. Como função principal, na visão dos moradores, a mata ciliar é importante para o controle da erosão das margens do Rio Quilombo, preservando a área de moradia da população. 
Lima (1989) ressalta que a localização desta vegetação, junto aos corpos d'água, faz com que ela possa desempenhar importantes funções hidrológicas, compreendendo: "proteção da zona ripária, filtragem de sedimentos e nutrientes, controle do aporte de nutrientes e de produtos químicos aos cursos d'água, controle das ribanceiras dos canais e controle da alteração da temperatura do ecossistema aquático".

O técnico do ITESP responsável pelo assentamento comenta que a população local não só respeita a mata ciliar como áreas de preservação permanente pelo Código Florestal (Lei 4771, de 1965), mas também, após a implantação do assentamento, houve uma recuperação da mata nativa. Isto se deve ao fato dos assentados sempre promoverem reflorestamento através de mutirões.

"É possivel, hoje, ver a recuperação da mata ciliar. Se você tivesse visto como ela estava antes da implantação do assentamento e vê como está hoje, concluiria que os moradores deram nova vida para a mata".

Um dos entrevistados ressalta a importância da mata e também vê a possibilidade de utilizá-la para o desenvolvimento da apicultura: "A Apicultura é uma atividade que não prejudica a mata e ao mesmo tempo auxilia na nossa renda familiar. Tem um apicultor que pediu a alguns moradores para colocar colméias no fundo da nossa casa, onde fica a mata ciliar. Muitos de nós autorizamos e sempre que ele vem colher o mel sempre deixa um pouco, um litro ou às vezes mais, para cada um".

O equilíbrio dos ecossistemas aquáticos depende diretamente da proteção da vegetação ripária, que age como reguladora das características químicas e físicas da água dos rios, mantendo-as em condições adequadas para a sobrevivência e reprodução da ictiofauna. Apesar do seu papel relevante na manutenção da biodiversidade, a preservação das florestas situadas às margens dos rios, ao redor de nascentes, lagos e reservatórios, baseou-se, sobretudo, no papel desempenhado por elas na proteção dos recursos hídricos.

Uma moradora local relatou que: "o rio Quilombo já chega poluido no 
assentamento. Acredito que ao passar em nossas terras ele consiga respirar um pouco. É uma pena que o espaço que ele passa aqui é muito pequeno, nem dá para ele se limpar de novo".

Estudos sobre o papel das florestas ripárias confirmam a hipótese de que elas atuam como filtros da água que atravessa o conjunto de sistemas componentes da bacia de drenagem, sendo determinantes, também, das características físicas, químicas e biológicas dos corpos d'água (Delitti, 1989).

Os moradores, ao receberem suas terras, sabiam que não poderiam desenvolver nenhum tipo de atividade econômica na área onde está localizada a mata ciliar, sendo esta uma área comunitária de preservação ambiental. Entretanto, percebe-se em conversas com os mesmos, que eles não conseguem ver a mata desvinculada de sua propriedade, ou seja, na sua percepção, ela faz parte do seu pedaço de terra e é seu dever preservá-la. Dessa forma é criado um vínculo de responsabilidade do assentado com o pedaço de mata ciliar que se situa em sua área e nas áreas circunvizinhas, originando assim não só a responsabilidade local, mas também a responsabilidade global de preservação.

Observou-se, portanto, que há uma real preocupação com a função protetora da mata ciliar para os produtores familiares do Sumaré II.

\subsection{Representação ecológica do produtor familiar do Sumaré II}

\subsubsection{Criação do IREc (Índice de Representação ecológica)}

Das perguntas do questionário foram selecionadas 12 delas (Anexo 2) para a criação do IREc. Em cada uma destas questões, foram verificadas todas as respostas dadas pelos entrevistados, criando-se assim um banco de itens.

Numa segunda etapa foram escolhidos cinco juízes, denominados aqui $\mathbf{j} 1$, $\mathrm{j} 2, \mathrm{j} 3, \mathrm{j} 4$ e $\mathrm{j} 5$, para dar notas aos itens. Estas notas, variando de -5 a 5 pontos, tiveram por objetivo classificar os itens de acordo com a sua ịmportância ecológica dentro de cada pergunta. Assim, o valor -5 (menos cinco) era atribuído ao item se o juiz o considerava 
como "ecologicamente incorreto" enquanto que o valor 5 (cinco) atribuído ao item significava que o juiz considerava o ato praticado pelo assentado como ecologicamente correto. As notas dos juízes a cada um dos itens encontram-se no Apêndice 4.

Uma primeira análise foi realizada com as notas dadas pelos juízes, visando verificar se havia discriminação entre elas. Utilizou-se o teste de Friedman com o intuito de saber o comportamento das notas e diferenças existentes entre os juízes. Este teste mostra que existem diferenças entre os juízes $(S=30,16 \mathrm{com} p$-valor $<0,0001)$. Complementando o teste de Friedman, utilizou-se o teste de comparações múltiplas (Pontes, 2000). Este mostrou que os juízes 1 e 5 são similares no valor mediano de suas notas; por outro lado, tem-se o grupo formado pelos juízes 2,3 e 4 , que não diferem entre si em relação à nota mediana, é possível ainda verificar a similaridade das notas médias dadas pelos juízes através da análise de agrupamentos (cluster analysis). A técnica de agrupamento utilizada foi hierárquica aglomerativa, ou seja, iniciou-se com cinco grupos e realiza-se a junção dos elementos ou grupos mais similares para a obtenção dos novos grupos. Para tal fim o método hierárquico de agrupamento de Ward, que forma grupos maximizando a homogeneidade dentro dos grupos (ou seja, minimizando o total das somas de quadrados dentro de grupos). Como trata-se de agrupamento de variáveis (juizes), utilizou-se o coeficiente de correlação amostral como medida de similaridade para que fossem efetuados os agrupamentos. $O$ dendrograma (fig.04) nos mostra que os juízes 2 e 3 deram notas de forma bastante similar (nível de similaridade igual a 98,8). Os juízes 1 e 5 passam a formar outro agrupamento (cluster), com grau de similaridade igual a 87,4 . O juiz 4 só é incorporado a este agrupamento quando o grau de similaridade atinge 80,5. As duas análises diferem em forma e conteúdo. Enquanto o teste de Friedman verifica diferenças entre medianas e as comparações múltiplas formam grupos com medianas semelhantes, na análise de cluster o que interessa é a forma como as notas são atribuídas aos itens. Percebe-se, com esta análise, que os juízes têm visões diferentes relacionadas aos atos praticados relacionados ao meio ambiente. Esta diversificação de idéias e opiniões torna mais consistente o sistema de atribuição de notas, gerando assim maior confiabilidade nos resultados obtidos. 
Na seqüência foi feita a análise referente ao Índice de Representação Ecológica (IREc), construído a partir da metodologia descrita no capítulo 3.

A tabela 16 mostra os passos para a construção dos agrupamentos referente à semelhança entre os juízes, informando o número de clusters, o nível de similaridade, o nível de distância, quais clusters foram unidos, a designação do novo cluster e o número de observações no cluster criado, em cada passo do processo.

\section{Similaridade}

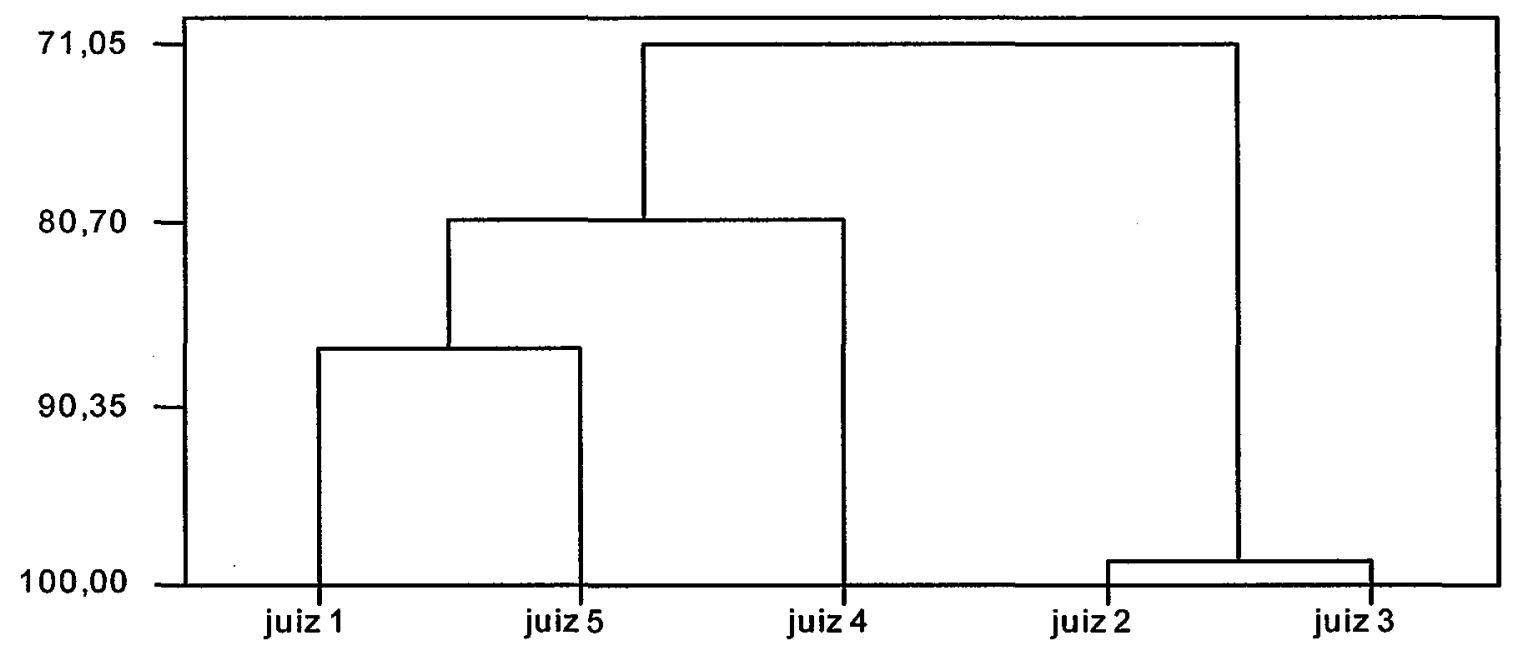

Figura 3 - Dendograma: similaridade entre os juízes.

Tabela 16. Passos de construção dos agrupamentos - semelhança entre os juízes.

\begin{tabular}{ccccccc}
\hline Passo & $\begin{array}{c}\mathrm{N}^{\circ} \text { de } \\
\text { clusters }\end{array}$ & $\begin{array}{c}\text { Nível de } \\
\text { Similaridade }\end{array}$ & $\begin{array}{c}\text { Nível de } \\
\text { distância }\end{array}$ & $\begin{array}{c}\text { Clusters } \\
\text { unidos }\end{array}$ & $\begin{array}{c}\text { Novo } \\
\text { cluster }\end{array}$ & $\begin{array}{c}\mathrm{N}^{\circ} \text { de observações } \\
\text { no novo cluster }\end{array}$ \\
\hline 1 & 4 & 98,78 & 0,024 & 2 e 3 & 2 & 2 \\
2 & 3 & 89,82 & 0,204 & 1 e 5 & 1 & 2 \\
3 & 2 & 85,26 & 0,295 & 1 e 4 & 1 & 3 \\
4 & 1 & 70,41 & 0,592 & 1 e 2 & 1 & 5 \\
\hline
\end{tabular}

Na Tabela 17, são apresentadas as notas médias dos juízes para cada entrevistado ou casa $\left(m_{-} \mathrm{j}\right)$, bem como a classificação ou rank $\left(\mathrm{r}_{\mathrm{j}} \mathrm{j}\right)$ levando-se em conta 
apenas o referido juiz. Os resultados apresentados mostram a diversidade de opiniões dos juízes e como isto afeta a classificação dos entrevistados. Em alguns casos, esta alteração é mínima. Por exemplo, o entrevistado da casa 17 tem classificação 1 (ou seja, menor visão ambiental) para quatro dos cinco juízes e classificação 2 para o outro. Outro exemplo de alteração mínima ocorre na casa 5, onde a classificação varia de 18,5 (para o juiz 1) até o maior valor de classificação (27, para os juízes 2, 3 e 4). Por outro lado, o valor do IREc do entrevistado da casa 9 é baixo para os juízes 1,4 e 5 e alto para os juízes 2 e 3. Outros casos semelhantes ocorrem com os entrevistados das casas 7, 10 e 18 , dentre outros.

Tabela 17. Média e classificação dada pelos juízes, feita de forma separada.

\begin{tabular}{|c|c|c|c|c|c|c|c|c|c|c|}
\hline CASA & $\mathrm{m} \mathrm{j} 1$ & $\mathrm{r} \mathbf{j} 1$ & $\mathrm{~m} \mathrm{j2}$ & $\mathrm{r} \mathrm{j} 2$ & $\mathrm{~m} \mathrm{j} 3$ & $\mathrm{rj} 3$ & $\mathrm{~m} \mathrm{j4}$ & $\mathrm{r} \mathrm{j} 4$ & $\mathrm{~m} \mathrm{j5}$ & $\mathrm{r} \mathrm{j} 5$ \\
\hline 1 & 3,833 & 21,0 & 2,667 & 16,5 & 2,917 & 17,0 & 2,048 & 13,0 & 3,417 & 15,0 \\
\hline 2 & 4,259 & 24,0 & 4,519 & 25,0 & 4,556 & 26,5 & 4,292 & 24,0 & 3,685 & 23,0 \\
\hline 3 & 2,119 & 1,0 & 1,500 & 6,0 & 1,690 & 6,0 & 1,528 & 9,0 & 3,238 & 10,0 \\
\hline 4 & 3,338 & 15,0 & 2,190 & 12,0 & 2,417 & 13,0 & 2,005 & 12,0 & 3,358 & 13,0 \\
\hline 5 & 3,667 & 17,5 & 4,630 & 26,0 & 4,481 & 25,0 & 4,750 & 27,0 & 3,796 & 24,0 \\
\hline 6 & 4,370 & 25,0 & 2,593 & 15,0 & 3,111 & 19,0 & 4,000 & 22,0 & 3,630 & 22,0 \\
\hline 7 & 3,556 & 16,0 & 1,426 & 4,0 & 1,889 & 8,0 & 3,250 & 21,0 & 3,481 & 19,0 \\
\hline 8 & 3,796 & 20,0 & 4,667 & 27,0 & 4,556 & 26,5 & 4,354 & 25,0 & 3,889 & 26,5 \\
\hline 9 & 708 & 4,0 & 3,667 & 24,0 & 3,292 & 21,5 & 1,143 & 5,0 & 3,125 & 4,5 \\
\hline 10 & 2,852 & 6,0 & 3,074 & 20,0 & 2,889 & 16,0 & 2,708 & 16,0 & 3,259 & 11,0 \\
\hline 11 & 458 & 2,0 & 2,083 & 10,0 & 2,167 & 11,0 & 2,143 & 14,0 & 3,125 & 4,5 \\
\hline 12 & 3,296 & 12,0 & 2,667 & 16,5 & 3,148 & 20,0 & 1,271 & 6,0 & 3,352 & 12,0 \\
\hline 14 & 3,942 & 22,0 & 3,208 & 21,0 & 3,292 & 21,5 & 2,148 & 15,0 & 3,629 & 21,0 \\
\hline 15 &, 042 & 23,0 & 2,750 & 18,0 & 2,750 & 15,0 & 2,762 & 17,0 & 3,583 & 20,0 \\
\hline 16 & ,333 & 13,5 & 2,238 & 13,0 & 2,354 & 12,0 & 1,857 & 11,0 & 3,229 & 9,0 \\
\hline 17 & 2,646 & 3,0 & $-0,458$ & 1,0 & 0,042 & 1,0 & 0,167 & 1,0 & 2,667 & 1,0 \\
\hline 18 & 3,667 & 17,5 & 1,444 & 5,0 & 1,630 & 4,0 & 3,208 & 20,0 & 3,185 & 8,0 \\
\hline 19 & 3,204 & 11,0 & 2,167 & 11,0 & 2,111 & 9,0 & 0,938 & 4,0 & 3,167 & 7,0 \\
\hline 20 & 3,707 & 19,0 & 1,218 & 3,0 & 1,737 & 7,0 & 1,708 & 10,0 & 3,370 & 14,0 \\
\hline 21 & 3,021 & 7,0 & 1,854 & 8,0 & 2,142 & 10,0 & 3,190 & 19,0 & 2,921 & 2,0 \\
\hline 22 & 3,167 & 10,0 & 2,000 & 9,0 & 1,667 & 5,0 & 0,200 & 2,0 & 3,000 & 3,0 \\
\hline 23 & 4,556 & 27,0 & 3,593 & 23,0 & 3,556 & 24,0 & 4,250 & 23,0 & 3,889 & 26,5 \\
\hline 24 & 3,333 & 13,5 & 2,417 & 14,0 & 2,444 & 14,0 & 1,500 & 8,0 & 3,444 & 17,0 \\
\hline 25 & 2,810 & 5,0 & 1,639 & 7,0 & 1,571 & 3,0 & 1,333 & 7,0 & 3,429 & 16,0 \\
\hline 26 & 4,426 & 26,0 & 2,815 & 19,0 & 3,000 & 18,0 & 3,000 & 18,0 & 3,815 & 25,0 \\
\hline 28 & 3,125 & 9,0 & 3,333 & 22,0 & 3,417 & 23,0 & 4,429 & 26,0 & 3,458 & 18,0 \\
\hline 29 & 3,074 & 8,0 & 0,481 & 2,0 & 1,370 & 2,0 & 0,917 & 3,0 & 3,148 & 6,0 \\
\hline
\end{tabular}


Observa-se ainda que, excluindo a nota média do juiz 2 consignada ao entrevistado da família 17 (nota $-0,100$ ), todas as outras notas foram positivas, indicando assim que, na opinião dos juízes, há uma visão ambiental positiva entre os entrevistados.

Na tabela 18 é fornecido o IREc para cada família e a classificação final, de acordo com este índice.

Tabela 18. IREc e classificação através deste índice.

\begin{tabular}{rrr}
\hline \multicolumn{1}{l}{ CASA } & IREC & Classificação IREc \\
\hline 5 & 4,265 & 1 \\
2 & 4,262 & 2 \\
8 & 4,252 & 3 \\
23 & 3,969 & 4 \\
28 & 3,552 & 5 \\
6 & 3,541 & 6 \\
26 & 3,411 & 7 \\
14 & 3,244 & 8 \\
15 & 3,177 & 9 \\
1 & 2,976 & 10 \\
10 & 2,956 & 11 \\
9 & 2,787 & 12 \\
12 & 2,747 & 13 \\
7 & 2,720 & 14 \\
4 & 2,662 & 15 \\
24 & 2,628 & 16 \\
18 & 2,627 & 17 \\
21 & 2,626 & 18 \\
16 & 2,602 & 19 \\
11 & 2,395 & 20 \\
20 & 2,348 & 21 \\
19 & 2,317 & 22 \\
25 & 2,156 & 23 \\
3 & 2,015 & 24 \\
22 & 2,007 & 25 \\
29 & 1,798 & 26 \\
17 & 1,013 & 27 \\
\hline & &
\end{tabular}

Percebe-se, por esta classificação, que os entrevistados classificados nos níveis iniciais e finais tiveram notas menos variáveis do que os medianamente 
classificados. Ou seja, em geral, as opiniões dos juízes não diferiram muito no que concerne aos entrevistados com pouca visão ambiental e aos entrevistados com bastante visão ambiental.

Por outro lado, uma classificação que levasse em conta um maior número de classes seria problemática. Neste último caso, a formação teórica-prática dos juízes teria uma influência decisiva no resultado, e poderia levar a conclusões diferentes.

Observa-se que todos os valores do IREc foram positivos, indicando visão preocupada com o meio ambiente, na prática, por parte dos entrevistados.

Para realizar a classificação dos entrevistados em classes de representação ecológica, utilizando o IREc, calculou-se os pontos de corte para cada classe.

Inicialmente foi feita uma classificação puramente matemática, observando amplitudes iguais para cada classe. Assim, verificando-se que o valor mínimo é 1,013 e que o valor máximo é 4,265 , e considerando $g$ como o número do grupo, os pontos de corte, que se encontram na tabela 19, são dados por:

$$
L S_{g}=1,013+\frac{g \times(4,265-1,013)}{3}=1,013+1,084 g
$$

Tabela 19. Limites inferiores e superiores dos grupos.

\begin{tabular}{ccc}
\hline GRUPOS & Limite Inferior & Limite Superior \\
\hline 1 & 1,013 & 2,097 \\
2 & 2,097 & 3,181 \\
3 & 3,181 & 4,265 \\
\hline
\end{tabular}

Com este tipo de divisão dos grupos tem-se:

a) Grupo 1: menores valores do IREc - entrevistados pertencentes às famílias 3, 17, 22 e 29;

b) Grupo 2: valores medianos do IREc - entrevistados pertencentes às famílias $1,4,7,9,10,11,12,15,16,18,19,20,21,24$ e 25 ;

c) Grupo 3: valores maiores do IREc - entrevistados pertencentes às famílias $2,5,6,8,14,23,26$ e 28 . 
Foi também aplicado outro método classificatório, visando verificar a similaridade entre as famílias no que concerne à representação ambiental. $\mathrm{O}$ método de agrupamento (cluster analysis) visa agrupar famílias com notas médias semelhantes em forma e conteúdo. Foram utilizadas, para este fim, as médias ponderadas das notas dos cinco juízes. $\mathrm{O}$ método de cluster pode utilizar distâncias e métodos de ligação diferentes. Neste caso utilizou-se a distância Euclidiana, que é uma medida de dissimilaridade já que todos os valores são dados na mesma unidade e são contínuos. $\mathrm{O}$ método de ligação foi o mesmo utilizado na classificação dos juízes, ou seja, o método de Wald.

A figura 04 apresenta o dendrograma, obtido a partir das médias ponderadas dos juízes e foi estabelecido o ponto de corte igual a zero (faixa vermelha no gráfico). Assim, três grupos foram formados:

i) assentados considerados com menor representação ambiental: entrevistados das famílias $3,25,11,20,29,19,22$ e 17;

ii) assentados considerados com maior representação ambiental: entrevistados representantes das famílias $2,5,8,6,23$ e 28 , respectivamente;

iii) assentados considerados com média representação ambiental: entrevistados representantes das famílias $1,14,15,26,10,4,16,24$, $9,12,7,18$ e 21 .

A escolha do número de grupos e do ponto de corte para a formação dos mesmos foi arbitrária. Pontos de cortes diferentes poderiam levar à formação de novos subgrupos dentro dos grupos referidos. $\mathrm{O}$ resultado apresentado pela análise de agrupamentos é equivalente ao que se obteria através do IREc se os pontos de corte os da tabela 20.

Tabela 20. Pontos de corte para o IREc, considerando a divisão em três grupos.

\begin{tabular}{ccc}
\hline GRUPOS & Limite Inferior & Limite Superior \\
\hline 1 & 1,0 & 2,5 \\
2 & 2,5 & 3,5 \\
3 & 3,5 & 4,5 \\
\hline
\end{tabular}




\section{S im ilaridade}

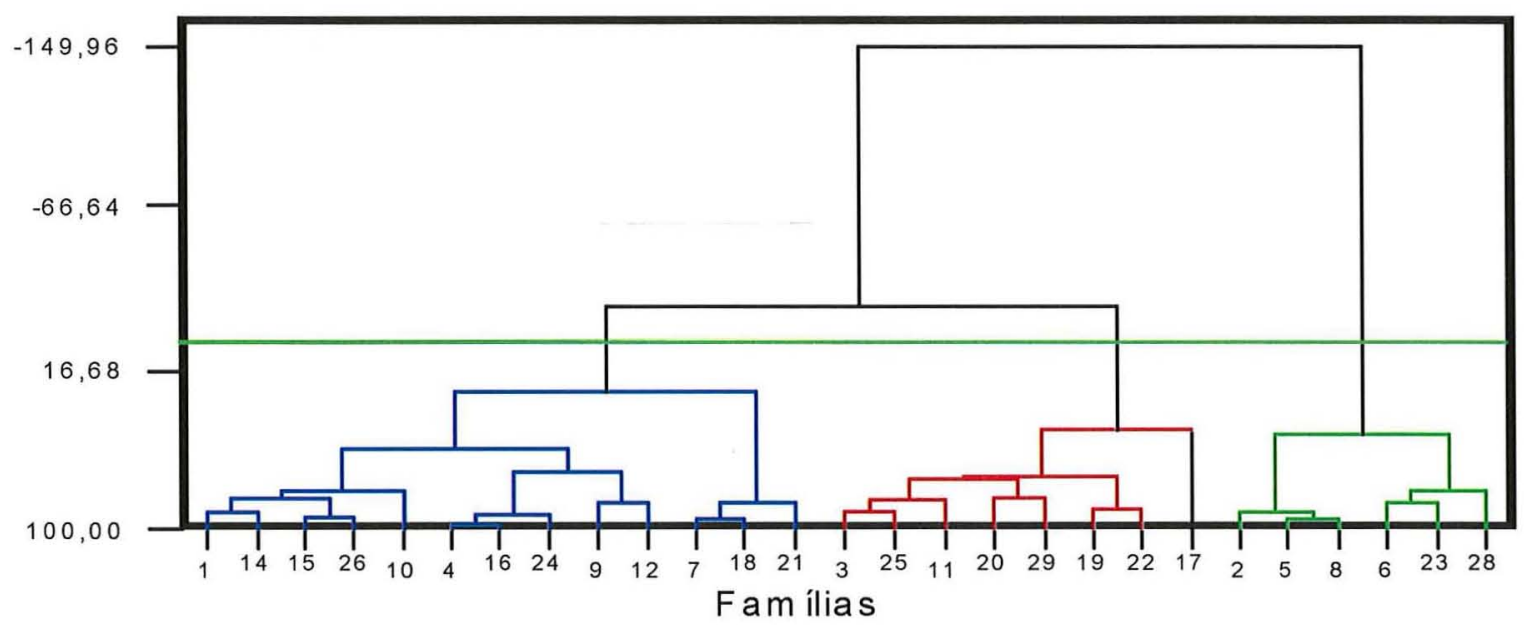

Figura 4 - Dendrograma: similaridade entre as famílias.

A tabela 21 mostra a formação dos grupos através da análise de agrupamentos. Nesta tabela são apresentados os passos $i$ da formação dos agrupamentos. A cada passo é informado o número de clusters (que vai decrescendo de 26 a 1), o nível de similaridade entre os grupos ou observações que foram unidos no passo $i$, o nível de distância (que vai aumentando a cada passo), quais clusters foram agrupados no passo $i$, o número do novo cluster formado e o seu número de observações. Com estas informações é possível saber detalhadamente que grupos são formados, o grau de semelhança entre os grupos ou observações, etc. O dendrograma da figura 4 explicita estas informações de forma pictórica.

Os resultados apresentados pelo IREc e pela análise de cluster, quando se observam os grupos extremos (de maior e de menor representação ambiental), são semelhantes. Entretanto, se a divisão for idealizada para um número maior de classes, percebe-se que os resultados tornam-se discrepantes devido às diferenças nas classificações nos grupos intermediários. Tais diferenças ocorrem devido à dessemelhança entre os juízes. 
Tabela 21. Análise de agrupamentos hierárquica das observações utilizando distância Euclidiana e ligação de Ward.

\begin{tabular}{ccccccc}
\hline Passo & $\begin{array}{c}\mathrm{N}^{\circ} \text { de } \\
\text { clusters }\end{array}$ & $\begin{array}{c}\text { Nível de } \\
\text { Similaridade }\end{array}$ & $\begin{array}{c}\text { Nível de } \\
\text { distância }\end{array}$ & $\begin{array}{c}\text { Clusters } \\
\text { unidos }\end{array}$ & $\begin{array}{c}\text { Novo } \\
\text { cluster }\end{array}$ & $\begin{array}{c}\mathrm{N}^{\circ} \text { de observações } \\
\text { no novo cluster }\end{array}$ \\
\hline 1 & 26 & 97.45 & 0.211 & 4 e 16 & 4 & 2 \\
2 & 25 & 95.04 & 0.412 & 7 e 18 & 7 & 2 \\
3 & 24 & 94.76 & 0.435 & 5 e 8 & 5 & 2 \\
4 & 23 & 93.14 & 0.570 & 15 e 26 & 15 & 2 \\
5 & 22 & 92.63 & 0.612 & 4 e 24 & 4 & 3 \\
6 & 21 & 91.47 & 0.708 & 1 e 14 & 1 & 2 \\
7 & 20 & 91.31 & 0.722 & 2 e 5 & 2 & 3 \\
8 & 19 & 90.79 & 0.764 & 3 e 25 & 3 & 2 \\
9 & 18 & 89.24 & 0.894 & 19 e 22 & 19 & 2 \\
10 & 17 & 86.55 & 1.116 & 7 e 21 & 7 & 3 \\
11 & 16 & 85.95 & 1.167 & 6 e 23 & 6 & 2 \\
12 & 15 & 85.58 & 1.198 & 9 e 12 & 9 & 2 \\
13 & 14 & 85.17 & 1.231 & 3 e 11 & 3 & 3 \\
14 & 13 & 84.04 & 1.325 & 20 e 29 & 20 & 2 \\
15 & 12 & 83.34 & 1.383 & 1 e 15 & 1 & 4 \\
16 & 11 & 79.92 & 1.667 & 6 e 28 & 6 & 3 \\
17 & 10 & 79.37 & 1.713 & 1 e 10 & 1 & 5 \\
18 & 9 & 73.52 & 2.198 & 3 e 20 & 3 & 5 \\
19 & 8 & 72.09 & 2.317 & 3 e 19 & 3 & 7 \\
20 & 7 & 70.67 & 2.435 & 4 e 9 & 4 & 5 \\
21 & 6 & 58.29 & 3.463 & 1 e 4 & 1 & 10 \\
22 & 5 & 50.63 & 4.099 & 2 e 6 & 2 & 6 \\
23 & 4 & 48.76 & 4.254 & 3 e 17 & 3 & 8 \\
24 & 3 & 28.18 & 5.962 & 1 e 7 & 1 & 13 \\
25 & 2 & -15.95 & 9.626 & 1 e 3 & 1 & 21 \\
26 & 1 & -149.96 & 20.752 & 1 e 2 & 1 & 27 \\
\hline
\end{tabular}

A figura 5 mostra os valores do IREc, por ordem crescente, e os grupos formados através deste índice. Verifica-se que as famílias 5, 2 e 8 formam um grupo homogêneo, com altos valores do IREc. No outro extremo, a família 17 apresenta um índice com valor bem inferior às demais. Percebe-se ainda uma homogeneidade nos valores dos índices das famílias classificadas no grupo mediano, o que pode gerar uma certa dificuldade na classificação das famílias nos grupos. 


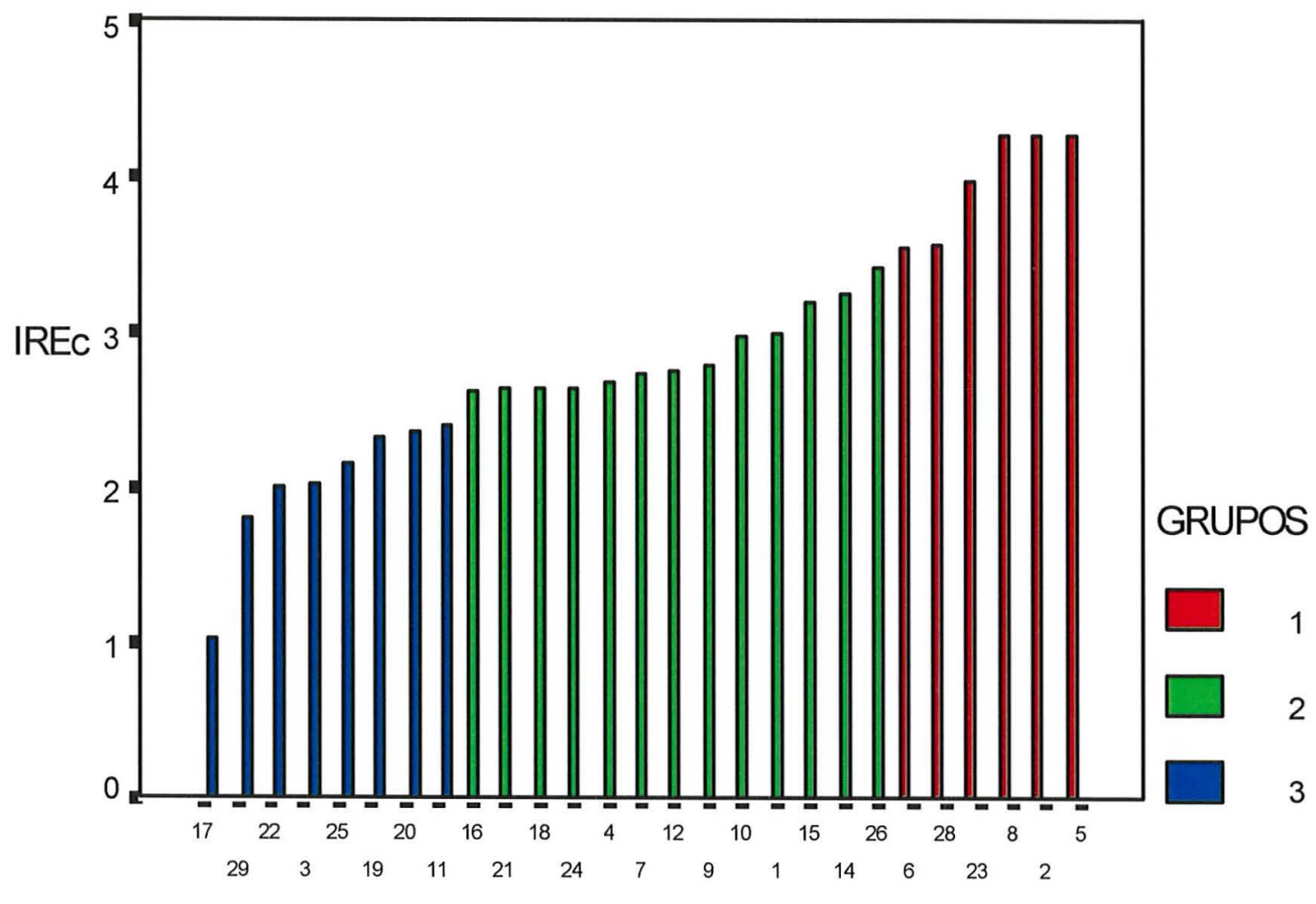

\section{Famílias por ordem crescente do IREc}

Figura 5 - Famílias por ordem crescente do IREc e grupos formados.

Numa situação em que seja constatada a semelhança entre as notas de todos os juízes para cada elemento observado, ambos os métodos apresentariam resultados praticamente equivalentes. Neste caso, os valores individuais seriam próximos das respectivas médias e a variação dentro de cada grupo seria mínima. Assim, os agrupamentos obtidos pelo método de Wald e com distância euclidiana, tenderiam a ser realizados através de valores médios, como no IREc.

Por outro lado, o método do IREc, por considerar a média dos juízes para a classificação dos entrevistados, é mais consistente quando tem-se juízes com opiniões discrepantes, como é o caso em pauta. Além disso, a análise de agrupamentos pode apresentar resultados diferentes de acordo com a distância e o método de ligação utilizado, o que a torna inadequada em muitas situações. Assim, o método do IREc pode ser recomendado em ambas as situações. 
$\mathrm{Na}$ etapa seguinte, buscou-se verificar se havia relacionamento entre o Índice de Representação Ecológica (IREc) e as variáveis renda per capita, idade do titular, idade média dos moradores do lote, percentual de pessoas do sexo masculino, instrução do titular, instrução média dos moradores do lote e instrução mediana dos moradores do lote.

Apenas para a variável instrução média dos moradores houve uma correlação linear significativa com o valor do IREc com um coeficiente de correlação igual $39,8 \%$.

Foi obtida, então, a reta de regressão referente à influência da instrução média dos moradores da casa sobre o valor do IREc, dada por

$$
I R E c=1,87+0,356 x \text { (Instrução Média dos Moradores do Lote) }
$$

A declividade da reta de regressão foi significativa, com um $p$-valor igual a 0,040. Entretanto, o coeficiente de determinação $\left(\mathrm{R}^{2}\right)$ foi pequeno $(15,8 \%)$, ou seja, apenas este percentual da variação do IREc pode ser explicada pela variável instrução média dos moradores. Observa-se que o coeficiente da regressão quadrática não foi significativo e o acréscimo no coeficiente de explicação foi muito pequeno (aumentou para 18,5\%). Assim, este tipo de regressão foi descartado para este caso.

A tabela 22, com os resultados da análise de regressão, e a figura 7, com a nuvem de pontos e a reta de regressão ajustada, são apresentadas.

Esta relação pode ser observada na tabela 23, onde se tem as médias do IREc dentro de cada um dos grupos de graus de instrução, tanto para o titular como para a instrução média dos moradores do lote.

Observa-se que a instrução média foi obtida apenas para os moradores em idade escolar e tomando-se a média dos valores obtidos nas respostas dos questionários, ou seja, 0 (zero) para analfabeto, 1(um) para semi-analfabeto, etc., até 6 (seis) para curso superior completo. Esta metodologia pode ser questionável. Mas, quando se trata de instrução, qualquer outra metodologia também poderia ser questionável. Uma possibilidade seria tomar o nível máximo de instrução do lote, supondo que haveria uma certa influência do elemento que tem este nível sobre os demais do lote. Entretanto não se constatou in loco esta influência de elementos com maior instrução pois, em geral, eram pessoas mais 
jovens e que, por conta do estudo, não tinham tanta experiência agrícola como os demais. Por outro lado, a utilização do nível de instrução do titular do lote também não refletiria a realidade vivida no assentamento já que, nem sempre, o titular era a pessoa mais influente sobre os demais.

Tabela 22. Quadro de análise de regressão.

\begin{tabular}{|c|c|c|c|c|c|}
\hline $\begin{array}{l}\text { Causa de } \\
\text { Variacão }\end{array}$ & $\begin{array}{c}\text { Graus de } \\
\text { Liberdade }\end{array}$ & $\begin{array}{c}\text { Somas de } \\
\text { Quadrados }\end{array}$ & $\begin{array}{l}\text { Quadrados } \\
\text { Médios }\end{array}$ & $\begin{array}{l}\text { Valor } \\
\text { de F }\end{array}$ & p-valor \\
\hline Regressão & 1 & 2,5605 & 2,5605 & 4,70 & $\overline{0,040}$ \\
\hline Resíduo & 25 & 13,6186 & 0,5447 & & \\
\hline Total & 26 & 16,1790 & & & \\
\hline
\end{tabular}

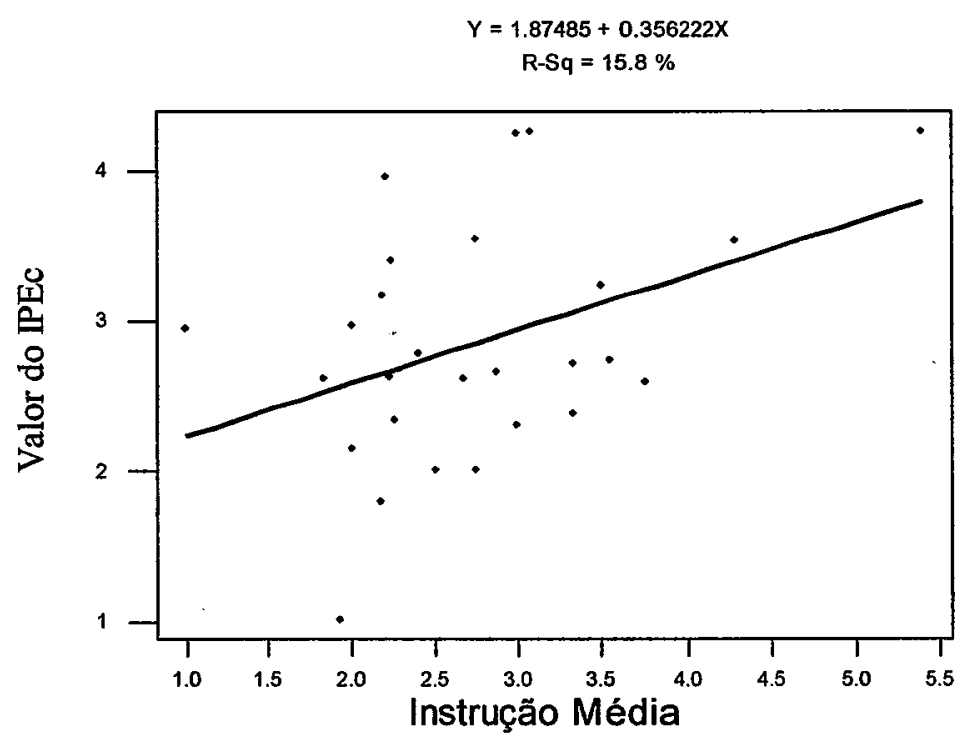

Figura 6 - Nuvem de pontos e reta de regressão ajustada.

Observa-se que a instrução média foi obtida apenas para os moradores em idade escolar e tomando-se a média dos valores obtidos nas respostas dos questionários, ou seja, 0 (zero) para analfabeto, 1(um) para semi-analfabeto, etc., até 6 (seis) para curso superior completo. Esta metodologia pode ser questionável. Mas, quando se trata de instrução, qualquer outra metodologia também poderia ser questionável. Uma 
possibilidade seria tomar o nível máximo de instrução do lote, supondo que haveria uma certa influência do elemento que tem este nível sobre os demais do lote. Entretanto não se constatou in loco esta influência de elementos com maior instrução pois, em geral, eram pessoas mais jovens e que, por conta do estudo, não tinham tanta experiência agrícola como os demais. Por outro lado, a utilização do nível de instrução do titular do lote também não refletiria a realidade vivida no assentamento já que, nem sempre, o titular era a pessoa mais influente sobre os demais.

Tabela 23. Médias, medianas, valores mínimos e máximos do IREc para cada grupo de graus de instrução do titular.

\begin{tabular}{lrrrrr}
\hline Instrução do Titular & N & Média & Mediana & Mínimo & Máximo \\
\hline Analfabeto & 2 & 2,073 & 2,073 & 1,798 & 2,348 \\
$1^{\circ}$ Grau Incompleto & 8 & 3,223 & 2,852 & 2,015 & 4,265 \\
$1^{\circ}$ Grau Completo & 11 & 2,837 & 2,976 & 1,013 & 3,969 \\
$2^{\circ}$ Grau Incompleto & 3 & 2,911 & 2,720 & 2,602 & 3,411 \\
$2^{\circ}$ Grau Completo & 2 & & 2,276 & 2,156 & 2,395 \\
Nível Superior & 1 & 2,628 & 2,628 & 2,628 & 2,628 \\
\hline
\end{tabular}

Tabela 24. Médias, medianas, valores mínimos e máximos do IREc para cada grupo de graus de instrução média dos moradores em idade escolar.

\begin{tabular}{lrrrrr}
\hline Instrução Média & N & Média & Mediana & Mínimo & Máximo \\
\hline Grupo 1 (menor ou igual a 1) & 1 & 2,956 & 2,956 & 2,956 & 2,956 \\
Grupo 2 (entre 1 e 2) & 17 & 2,724 & 2,628 & 1,013 & 4,265 \\
Grupo 3 (entre 2 e 3) & 3 & 3,002 & 2,720 & 2,317 & 3,969 \\
Grupo 4 (entre 3 e 4) & 3 & 2,747 & 2,602 & 2,395 & 3,244 \\
Grupo 5 (maior do que 4) & 3 & 3,517 & 3,541 & 2,747 & 4,262 \\
\hline
\end{tabular}

Buscou-se então outra análise, utilizando-se a regressão não-paramétrica e o coeficiente de correlação de Spearman, pois tanto o IREc como o nível de instrução foram medidos através de valores codificados. Para o cálculo das estimativas dos coeficientes da reta de regressão não-paramétrica, utilizou-se a estatística de Theil para a inclinação e de Hettmansperger-McKean-Sheater para o intercepto (Hollander \& Wolfe, 1999). A reta de regressão obtida por esta metodologia foi

$$
I R E c=1,6244+0,3235 x \text { (Instrução Média dos Moradores do Lote) }
$$


Para o teste do coeficiente de inclinação obteve-se significância (p-valor $=0,003$ ). Por outro lado, o coeficiente de correlação de postos (Coeficiente de correlação de Spearman) obtido foi 0,3126 cujo $p$-valor é um pouco acima de $5 \%$ (p-valor $=0,052$ ). Não ocorrem grandes alterações quando se utiliza a regressão paramétrica ou nãoparamétrica. Os valores apresentados para o coeficiente de correlação são próximos (0,398 e 0,313 para os coeficientes de Pearson e de Spearman, respectivamente) e, portanto, os coeficientes da inclinação da reta de regressão também o são $(0,356 \mathrm{e}$ 0,3235 para o caso paramétrico e não-paramétrico, respectivamente).

Assim, o IREc não apresentou relação com nenhuma das variáveis estudadas (idade, instrução, número de moradores do lote). Isto possivelmente ocorreu pelo fato de que o este índice agrega fatores não facilmente mensuráveis tais como compreensão do mundo que nos cerca, interação do homem-ambiente, etc. Tais fatores têm uma fraca conexão com a educação formal e têm uma ligação forte com uma visão estrutural do mundo em que se vive, e tal visão não é numericamente mensurável. A constatação deste fenômeno ocorre quando se tenta obter correlações entre variáveis de interesse e o IREc, e verifica-se que apenas o grau de educação médio familiar tem alguma (pequena) influência sobre o valor do IREc.

Para a obtenção do IREc foram utilizados, dentre outros, elementos de participação associativa (participação em reuniões e em mutirões, com suas respectivas motivações), preocupação ambiental (destino de embalagens tóxicas, uso de pesticidas, etc) e estes elementos dependem muito mais de uma postura pessoal frente à natureza do que de variáveis mensuráveis (idade, grau de instrução, etc).

Observa-se ainda que quando se calcula a regressão entre os postos do IREc e os postos da Instrução Média Familiar tem-se

$$
\text { Posto_IREc }=8,85+0,35 x \text { (Posto da Instrução Média) }
$$

Como para o elemento de posto 9 (o inteiro mais próximo de 8,85) no IREc, o valor do intercepto é 1,49 tem-se que a reta de regressão obtida com os postos é semelhante àquela obtida com os valores não transformados em postos, lembrando que neste último caso o intercepto é 1,64 e o coeficiente de inclinação da reta é 0,3235. 


\section{CONCLUSÕES}

A partir de um conjunto de técnicas, entre elas entrevistas, observações e de situações cotidianas do entorno onde vivem os moradores do Assentamento Sumaré II, buscou-se ter acesso às representações sociais destes. Entende-se não ser possível compreender como o meio ambiente é percebido sem fazer referência a esta noção, vista como uma atividade de reconstrução da realidade. As representações sociais foram sobre tudo abordadas enquanto construção do social, com o objetivo de compreender como os indivíduos organizam seu conhecimento no que se refere ao meio natural e como agem sobre eles. Para entender as representações foi necessário conhecer a história, a cultura e a experiência destes moradores no contexto de seu meio ambiente físico e social. E para melhor compreender a realidade do local, alguns aspectos importantes devem ser colocados neste capítulo.

A problemática sobre a questão dos produtos químicos utilizados na lavoura está presente no discurso de parte da população do assentamento. Mas, apesar de saberem os perigos do uso desses produtos, justificam seu uso e a opção pelo modo de cultivo convencional por acreditarem que ainda é a única forma de produzir para seu sustento e de sua família. Outra parte, apesar de ser um grupo ainda pequeno, vem tentando um sistema de produção que busca manejar de forma mais equilibrada o solo e os demais recursos naturais.

O mercado só considera produtos orgânicos aqueles que trazem em suas embalagens o nome "orgânico" juntamente com o selo de uma Instituição Certificadora. Este selo demonstra a quem comprou, que o alimento é isento de substâncias nocivas à saúde. Assim, a escolha do modo de produção convencional por alguns produtores 
familiares do local é justificada pela dificuldade de obter a certificação para os produtos cultivados dentro do Sumaré II, pois, como mencionado anteriormente, as áreas de cultivo são próximas e qualquer produto químico utilizado na área vizinha acaba afetando a área que produz agricultura semi-orgânica. Além disso, também tem a questão dos gastos para a obtenção da certificação do produto. E o produtor, sem ver outra alternativa para dar continuidade a sua sobrevivência e de sua família, continua, do seu modo, seu cultivo semi-orgânico ou convencional.

Sobre o desmatamento das áreas protegidas no assentamento Sumaré II, segundo o técnico do Itesp, as maiores destruições não foram causadas por desmatamentos predatórios do produtor local, mas sim pelos antigos proprietários da terra, que sem nenhum planejamento, visando a eliminação da mata nativa, promoveram danos irreparáveis à flora e à fauna nativas do local, atitudes irresponsáveis que levou à degradação da terra. É importante mencionar que os assentados logo que assumiram a terra, tomaram providências imediatas. Exemplo desta atitude foi demonstrada através de mutirões para o reflorestamento da área (mata ciliar e área não ocupada pela agricultura) e eventos que buscavam maior conscientização dos moradores.

Destaca-se também a necessidade da conservação ambiental e manutenção das reservas e áreas naturais, já que há interesse da implantação do turismo rural no assentamento. A importância do turismo rural é que, além desta atividade amenizar a degradação da área, ao mesmo tempo poderá auxiliar na renda familiar melhorando a qualidade de vida da população do Assentamento Sumaré II.

Para melhor avaliar os resultados, além da analise descritiva feita com os dados obtidos do questionário e observações de campo, obteve-se no presente trabalho um índice, denominado Índice de Representação Ecológica (IREc), que buscou reunir, numa única variável, parte das informações mencionadas, fornecendo uma medida sintética que facilita as análises e conclusões.

Pereira (1999) discute a necessidade de utilização de índices que tenham precisão e acuidade. Observa ainda, que os "conceitos aristotélicos" da manifestação de qualidades são: reconhecimento da oposição entre contrários, reconhecimento de situação intermediária e também do gradiente. Estes conceitos são observados no IREc 
através de notas negativas e positivas, nota nula e possível relatividade entre as notas dadas, respectivamente. Ao utilizar, para a construção do índice de Representação Ecológica (IREc), a média das notas dadas por juizes, isentos ou não ao fenômeno que está sendo estudado, buscou-se um índice que atendesse às recomendações do autor. Com a utilização de uma amplitude da escala utilizada para as notas a serem dadas pelos juízes de -5 a 5 , obteve-se uma maior precisão para o índice. Além disso, buscou-se uma melhor acuidade utilizando a média das notas dos juízes.

A utilização do IREc para comparações entre assentamentos é possível desde que o mesmo tipo de questionário seja aplicado, abordando as mesmas variáveis e ainda sejam utilizados os mesmos procedimentos para a escolha dos juízes. No caso em pauta, o IREc tem mais uma função: servir de base para ações futuras, no âmbito interno, com a colaboração dos moradores que obtiveram uma maior pontuação, com a finalidade de conscientizar os de menores pontuação. Por outro lado, pode também servir, através das características estudadas neste trabalho, para melhor direcionar ações que poderão ser desenvolvidas através de órgãos governamentais, ONG's e instituições acadêmicas dentro do assentamento Sumaré II.

Através do Índice de Representação Ecológica, buscou-se entender a realidade dentro do assentamento no que se refere à visão do produtor familiar com o meio ambiente. Contudo, ao tratar dos resultados obtidos pelo IREc e apesar deste estar ancorado em dados quantificáveis, é importante mencionar que quantificar a representação social humana é uma tarefa difícil, pois o objeto da pesquisa é a complexidade do Homem. Entretanto, o IREc mostrou em seus resultados fidedignidade e coerência com as observações de campo.

Os resultados apresentam coincidências evidentes com a análise de agrupamentos ("cluster analysis"), especialmente nas classes extremas. Quanto às classes intermediárias, o IREc e a análise de agrupamentos mostram resultados parcialmente iguais. Isto é inerente ao fato que os métodos utilizados são diferentes: o primeiro se baseia na média ponderada das notas dos juízes enquanto que o segundo tem como foco a distância entre as variáveis. Levando em conta que o interesse do pesquisador está não na similaridade de comportamentos e sim no comportamento 
médio de cada assentado em relação ao meio ambiente, o IREc reflete melhor a preocupação do pesquisador.

Ditt (2002), para verificar atitudes e comportamentos de conservação dos fragmentos florestais dos fazendeiros no Pontal do Paranapanema, desenvolveu um indicador aditivo. Para a criação deste indicador foi aplicado um questionário a 17 pessoas. Considerou-se, neste total, sete casais, onde ambos os cônjuges foram entrevistados, e três fazendeiros avaliados individualmente. Para a construção do indicador foram selecionadas sete perguntas semi-abertas, às quais foram atribuídas notas utilizando-se as escalas de três e de dois pontos, dependendo da pergunta. Os indicadores obtidos, que variaram de 7 a 16 pontos, foram calculados através da soma das notas atribuídas pelo pesquisador às respostas de cada um dos entrevistados. A partir dos valores dos indicadores, o autor dividiu os fazendeiros em seis grupos distintos em relação às atitudes e comportamentos; posteriormente, comparou esta divisão com a análise de agrupamento ("cluster analysis"), verificando similaridade entre os dois métodos. Algumas semelhanças na construção do indicador proposto por Ditt (2002) e o IREc são evidentes. Ambos utilizam indicadores aditivos e a análise de agrupamento para comparação dos seus resultados. A diferença entre ambos está, principalmente, na forma de atribuição de notas: enquanto que para a construção do primeiro utilizou-se a nota dada pelo pesquisador aos itens, no IREc foi calculada a média das notas de cinco juízes e, a escala utilizada para as atribuições de notas em cada item é mais ampla no caso do IREc. Assim, o número de valores possíveis do IREc é muito maior que o do indicador.

Observando os resultados obtidos pelo IREc, algumas características sobressaem:

a) todos os entrevistados obtiveram valores do IREc positivos, sendo o menor valor igual a 1,013 ;

b) dentre as 135 notas atribuídas aos entrevistados, apenas uma foi negativa;

c) nenhum entrevistado obteve nota máxima $(5,0)$ para o IREc e o maior valor foi 4,265 ; 
d) nove dos vinte e sete entrevistados $(33,3 \%)$ obtiveram valores do IREc acima de 3,2;

e) registraram-se apenas quatro valores do IREc menores do que 2,1 $(14,8 \%)$;

f) não foi encontrado relacionamento entre o IREc com outras variáveis medidas no trabalho (renda per capita, idade do titular, idade média dos moradores do lote, percentual de pessoas do sexo masculino, instrução do titular e instrução mediana dos moradores do lote); Ditt (2002) também não identificou, em seu trabalho, associação entre o indicador de atitudes e comportamentos com o sexo, a escolaridade, $o$ tempo de moradia na propriedade, a idade, o tempo de contato com a zona rural, a importância da propriedade rural na renda familiar e o número de familiares envolvidos com os negócios da propriedade;

g) para a variável instrução média dos moradores houve uma correlação linear significativa com o valor do $\operatorname{IREc}(\mathrm{r}=39,8 \%)$ e a reta de regressão obtida foi $I R E c=1,87+0,356 x$ (Instrução Média dos Moradores do Lote); apesar da declividade da reta de regressão ter sido significativa ( $\mathrm{p}$-valor $=0,040$ ), o coeficiente de determinação $\mathrm{R}^{2}$ foi de apenas $15,8 \%$;

Coerência dos resultados dessa análise permitiram observar, através do IREc, que há uma certa diversidade na concepção e nas ações dos moradores do Assentamento em relação ao meio ambiente. Apesar do intervalo de variação possível do IREc ser de -5 a 5 , os valores obtidos para este índice para os assentados do Sumaré II variaram de 1,013 a 4,265 indicando que existe uma manifestação positiva da importância ambiental para os entrevistados. Entretanto, quando são comparados os dados entre os moradores e a divisão em classes de representação, verifica-se que, internamente, existem moradores com maior consciência ecológica que outros. Esta diversidade interna é natural em qualquer grupo social, pois as pessoas que o formam têm origens diversas com concepções pessoais diversas advindas de formações diferentes. Muitas manifestações ecológicas têm sido presenciadas, suas organizações 
comunitárias são reconhecidas pela atuação em defesa do meio ambiente, o que pode ser uma forma de, no futuro, obter-se uma maior homogeneidade dentro do grupo, visando a conscientização para uma melhor utilização dos recursos naturais, o que significaria um aumento geral e, ao mesmo tempo, uma menor amplitude no índice de representação ecológica.

A quantificação das representações sociais através das ações do homem sobre o meio ambiente, tanto para fins comparativos (dentro e fora do ambiente que se está sendo estudado), como com o objetivo de servir de parâmetro para a adoção de políticas educacionais, tem sido uma fonte de preocupação dos pesquisadores em geral. Tendo em vista o caráter multifacetado desta qualificação, não é possível utilizar uma variável única para definir, mensurar ou ainda comparar a representação de agentes diferentes. Assim, é importante ter em mente que o $\mathbb{R E E c}$, por si só, não serve como balizador para tomada de ações referente ao meio ambiente. Entretanto sua utilização, em conjunto com observações de campo, pode ser um instrumento auxiliar valioso para o estudo e tomadas de decisões no que se refere a pesquisas voltadas à questão ambiental.

Como em toda investigação científica, o pesquisador, em sua busca da possível resposta a um problema específico, encontra novos desafios e caminhos a serem trilhados. Entretanto, é impossível dar a abrangência necessária e desejada ao tema em pauta num único trabalho. Assim, uma das metas da investigação científica é abrir novos rumos e novas trilhas para futuras investigações. Como sugestão para estudos posteriores foram elencados alguns temas em que se faz necessária uma maior investigação:

- Verificar com maior profundidade as influências de fatores internos e externos que levam o produtor familiar a utilizar as práticas do cultivo convencional para sua sobrevivência.

- Desenvolver estudos que visem identificar melhor a possibilidade da implantação de Sistema Agroflorestais e agricultura orgânica para atender a população local.

- Estudos que possam verificar a influência do Movimento dos Sem 
Terra (MST) na construção de representação social voltada às questões ambientais dentro dos assentamentos rurais.

- Tem-se consciência das limitações que o presente estudo poderá apresentar e, para melhor descrever as grandes dimensões do campo das representações sociais relacionadas às condições sócio-históricoculturais, é necessário o acréscimo de perguntas no questionário que melhor aprofundem estas questões. 


\section{REFERÊNCIAS BIBLIOGRÁFICAS}

AGUIAR, R.C. Abrindo o pacote tecnológico: estado e pesquisa agropecuária no Brasil. São Paulo: Polis/CNPq, 1986. 156p.

BEUS, C.E.; DUNLAP, R.E. Conflicting paradigms in agriculture. Rural Sociology, v.55, p.594-616, 1990.

BERGAMASCO, S.M.; NORDER, L.A.C. O que são assentamentos rurais. São Paulo: Brasiliense, 1996. 87p.

BRASIL. Ministério da Educação e do Desporto. Parâmetros curriculares nacionais: meio ambiente. http://www.bibvirt.fut.usp.br/textos/humanas/educação/pens/fundamental/ambiente/html\#index (17 fev. 2002)

BRÜGGER, P. Educação ou adestramento ambiental ? Florianópolis: Letras Contemporâneas, 1999. 159p.

DELVAL, J. Aprender na vida e aprender na escola. Porto Alegre: Ed. Artes Médicas, 2001. 201p.

DIEGUES, A.C. Etnoconservação da natureza: enfoques alternativos. In: DIEGUES, A.C. Etnoconservação: novos rumos para proteção da natureza nos trópicos. São Paulo: Hucitec, 2000. 290p. 
DITT, E.H. Fragmentos florestais no Pontal do Paranapanema. São Paulo: Annablume/Ipê /HEB, 2002. 140p.

DURKHEIM, E. As regras do método sociológico. São Paulo: Companhia Editora Nacional, 1968. 140p.

FAO. Activities related to sustainable agricultural development and environment: Document C91/30, Oct./1991. http://www.fao.org/waicent/search/default.asp (12 Jan. 2002)

FERRI, M.G. Ecologia e poluição. São Paulo: Melhoramentos, 1977. 160p.

HOLLANDER, M.; WOLFE, D.A. Nonparametric statistical methods. 2.ed. New York: John Wiley \& Sons, 1999. 787p.

HUGON, P. História das doutrinas econômicas. São Paulo: Atlas, 1969. 401p.

KITAMURA, P.C. O desenvolvimento sustentável da Amazônia. In: SHIKI, S.; SILVA, J.G.; ORTEGA, A.C. (Ed.). Agricultura, meio ambiente e sustentabilidade do cerrado brasileiro. Uberlândia: EMBRAPA/UNICAMP/UFU, 1997. p.121-133.

KUHNEN, A. Representações sociais de meio ambiente: estudo das transformações, apropriações e modos de vida na Lagoa da Conceição. Florianópolis, 2001. Tese (Doutorado) - Universidade Federal de Santa Catarina.

LEIS, H. Ecologia e política mundial. Rio de Janeiro: Vozes, 1991. 184p.

LEIS, H.; D'AMATO, J.L. O ambientalismo como movimento vital: análise de suas dimensões histórica, ética e vivencial. In: CAVALCANTE, C. (Org.). Desenvolvimento e natureza: estudo para uma sociedade sustentável. São Paulo: Cortez, 1995. 280p. 
LIMA, M.J. Ecologia humana: realidade e pesquisa. Petrópolis: Vozes, 1984. 163p.

LIMA, W.P. Função hidrológica da mata ciliar. In: SIMPÓSIO SOBRE MATA CILIAR, São Paulo, 1989. Anais. São Paulo: Fundação Cargill, 1989. p.25-42.

MAIMON, D. Ensaios sobre economia do meio ambiente. Rio de Janeiro: Editora APED, 1992. 187p.

MELO, J.C. Os 500 anos do Brasil \& a educação ambiental. http://umweltprogramme.de/meioambiente99/temao2/melo/texto.html (02 jul. 2002)

MINAYO, M.C.S. O desafio do conhecimento: pesquisa qualitativa em saúde. São Paulo: Hucitec/Abrasco, 1992. 269p.

MINAYO, M.C.S. Conceito de representações sociais dentro da sociologia clássica. In: GUARESCHI, P.A.; JOVCHELOVITCH, S. Textos em representações sociais. Petrópolis: Vozes, 1994. 324p.

MOSCOVICI, S. A representação social da psicanálise. Rio de Janeiro: Zahar Editores, 1978. $291 \mathrm{p}$.

NEDER, R.T. Política pública no Brasil: do conservacionismo ao paradigma da sustentabilidade. Piracicaba: ESALQ, Depto. de Economia, Administração e Sociologia, 1994. 47p. (Série Didática, 94)

PATERNIANI, E. Agricultura sustentável nos trópicos. Estudos Avançados, v.15, n.43, p.303-326, 2001.

PEREIRA, J.C.R. Análise de dados qualitativos: estratégias metodológicas para as ciências: saúde, humanas e sociais. São Paulo: EDUSP, 1999. 156p. 
PONTES, A.C.F.; CORRENTE, J.E. Obtenção de níveis de significância para experimentos em blocos casualizados e comparações múltiplas não-paramétricas. Revista de la Sociedad Argentina de Estadistica, v.1/2, n.4, p.179-197, 2000.

RÉGNIER, E.M. Educação ambiental: ponte para o amanhã. Boletim Técnico do Senac, v.27, n.1, p.17-20, jan./abr. 2001.

REIGOTA, M. Meio ambiente e representação social. 5.ed. São Paulo: Cortez, 2002. $87 \mathrm{p}$.

ROSA, A.V. Agricultura uma reação do homem com a terra. In: FURLAN, S.A.; SCARLATO, F. (Coord.). Agricultura e o meio ambiente. São Paulo: Atual, 1998. 95p.

ROSZAK, T. Persona/planeta: hacia un nuevo paradigma ecológico. Barcelona: Editorial Kairós, 1985. 125p.

SÁ, C.P. de. Representações sociais: o conceito e o estado atual da teoria. In: SPINK, M.J.P. (Org.). O conhecimento no cotidiano: as representações sociais na perspectiva da psicologia social. São Paulo: Brasiliense, 1993. 311p.

SACHS, I. Ecodesenvolvimento: crescer sem destruir. São Paulo: Vértice, 1986. 207p.

SILVA, J.G. da. A nova dinâmica da agricultura brasileira. Campinas: UNICAMP, Instituto de Economia, 1996. $211 \mathrm{p}$.

SILVA, J.G. da. O novo rural brasileiro. Campinas: UNICAMP, Instituto de Economia, 1999. 151p.

SILVA, J.G. da. Tecnologia \& agricultura familiar. Porto Alegre: Editora da Universidade do Rio Grande do Sul, 1999. 238p. 
SILVA, J.G. da. O que é questão agrária. 1.ed. São Paulo: Brasiliense, 1980. 109p.

SILVA, L.H. Relação educativa e alternância: representações sociais dos autores das experiências brasileiras de formação em alternância. São Paulo, 2000. Tese (Doutorado) - Pontifícia Universidade Católica de São Paulo.

THOMAS, K. O homem e o mundo natural. São Paulo: Companhia das Letras, 1989. $454 \mathrm{p}$.

TOLEDO, V.M. El juego de la supervivencia: manual para la investigação etnoecologica en Latinoamerica. Santiago de Chile: Consorcio Latinoamericano de Agroecologia y Desarrollo - CLADES, 1991. 75p.

VEIGA, E.J. da. Dossiês estatísticos: para detalhamento regionalizado das propostas contidas no relatório diretrizes de política agrária e desenvolvimento sustentável. São Paulo, 1995. http://www.desenvolvimentoagrario.gov.br/incra/fao/Diretrizes.htm (18 jun. 2002)

VIOLA, E.J.; LEIS, H.R. Desordem global da biosfera e a nova ordem internacional: o papel organizador do ecologismo. In: LEIS, H.R. (Org.). Ecologia e política mundial. Petrópolis: Vozes, 1991. 183p.

ZAMBERLAM, J.; FRONCHETI, A. Agricultura ecológica: preservação do pequeno agricultor e do meio ambiente. Petrópolis: Vozes, 2001. 214p. 


\section{APÊNDICES}


APÊNDICE 1 - Questionário: uso da terra.

data

código da família :

entrevistado:

1 - caracterização familiar

1.1 Ficha anexa

1.2- Há quanto tempo você mora no assentamento?

1.3- Onde morava antes de vir morar no assentamento? (cidade/estado)

1.4- Que atividade você desenvolvia antes de morar no assentamento?

1.5 - Depois que veio morar no assentamento sua vida:

( )1. melhorou ( )2-piorou ( )3-continua a mesma coisa

2 -Moradia

Tipo: ( ) 1-tijolo/bloco ( )2-taipa ( )3-pau-a-pique ( )4- madeira/tábua

Cobertura ( )1-cerâmica ( )2- telha eternit ( )3-amianto ( )4-palha ( )5- lona

Piso: ( ) 1-chão batido ( )2- cimentado ( )3-piso frio/ lajota

$\mathrm{N}^{\circ}$ de cômodos ( ) 1() 2() 3() 4() 5() 6() 7 ou mais

Fornecimento de água: ( ) 1-rio ( )2-poço ( )3- mina ( )4-semae

Água para beber: ( ) filtrada ( ) 1-fervida ( )2-tratada com cloro ( )3-semae ( )4-nenhum

Esgoto ( )1- fossa ( )2- semae ( )3- outros

Iluminação: ( )1- elétrica ( )2- lamparina/ vela ( $) 3$ não possui

Fogão: ( )1-gás ( )2-lenha

Eletrodomésticos: ( ) 1-geladeira ( )2- televisão ( )3-rádio ( )4- aparelho de som

( )5-liquidificado ( )6-freezer ()7-outros quais?

Telefone ( ) convencional ( ) celular ( ) não possui

3 - Atividade econômica: caracterização da ocupação da terra

3.1 Força de trabalho familiar não residente na casa:

\begin{tabular}{|l|l|}
\hline Quantos dias você contrata para trabalhar na produção? & Quanto você gasta? \\
\hline & \\
\hline & \\
\hline
\end{tabular}

3.2- Área utilizada para moradia:(ha)

3.3- Área de plantio(ha) 
3.4 - Você trabalha com processamento caseiro de alimentos para ajudar na renda familiar?

( )1- sim ( )2- não

Quais?_( )1-polpa de frutas ( )2- bolos, pães e doces( ) 3-mandioca descascada () 4- conservas( )

Qual a renda obtida em 2001?

3.5- Culturas- safra colhida em 2001.

\begin{tabular}{|c|c|c|c|c|c|c|}
\hline n. ${ }^{\circ}$ & 2-Especificar & $\begin{array}{c}\text { 3-Quant. } \\
\text { especificar unid. } \\
\text { de medida }\end{array}$ & 4-cultivo & $\begin{array}{l}\text { 4- Valor } \\
\text { obtido com } \\
\text { a produção }\end{array}$ & 5-comprador & $\begin{array}{l}\text { 6-Época } \\
\text { da venda }\end{array}$ \\
\hline & & & & & & \\
\hline 1 & & & & & & \\
\hline 2 & & & & & & \\
\hline 3 & & & & & & \\
\hline 4 & & & & & & \\
\hline 5 & & & & & & \\
\hline 6 & & & & & & \\
\hline 7 & & & & & & \\
\hline 8 & & & & & & \\
\hline 9 & & & & & & \\
\hline
\end{tabular}

\begin{tabular}{|lll|}
\hline Comprador & cultivo & época da venda \\
\hline $1-$ morador do bairro & $1-$ semi orgânico & 1- na colheita \\
\hline $2-$ moradores de outros bairro & 2 - convencional & 2 2- qdo precisa de dinheiro \\
\hline 3- ceasa & 3- qdo o preço é melhor \\
\hline 4- comerciantes ( varejão, supermercado, etc) & 4 - outros (especificar) \\
\hline $5-$ outros (especificar & \\
\hline
\end{tabular}

3.6 - Planta produtos orgânicos?

1-sim ( ) 2-não ( )

quais?

3.7 - O que você entende por agricultura orgânica?

3.8 - Qual é a área por ha de:

1-agricultura orgânica?

2-agricultura convencional?

3.9- Como tomou conhecimento sobre agricultura orgânica?

3.10 - Quais os motivos que levaria(ou) você à trabalhar com agricultura orgânica? (ordem de prioridade)

( ) 1-um novo mercado consumidor ( )2- gastos obtidos para a produção

( ) 3-preocupação com o meio ambiente ( ) 4-preocupação com a saúde do consumidor
() 5- orientação técnica
( ) 6-melhor preço
( )7- outros Quais? 
4 -Manejo

4.1. Tecnologia

\begin{tabular}{|l|l|l|l|}
\hline 1-Cultura & 2-Tipo de trabalho & 3-Adubação & 3-Sementes \\
\hline & & & \\
\hline & & & \\
\hline & & & \\
\hline & & & \\
\hline & & & \\
\hline
\end{tabular}

Tipo de trabalho

adubação

1- braçal

1- Química

Sementes

2- animal

2- Calagem

1- Própria

3- mecânica

2- compradas

3- Doadas

4.2 - Você recebe orientação profissional na produção convencional?

( ) 1- sim ( )2- não

Qual?

De quem?

5 - Relação com a natureza

5.1.1- Havia algum tipo de mata nativa quando você ocupou sua área?

( )1-sim ( )2- não

5.1.2 - Se sim, qual área?

1-Familiar( ) 2-produção ( ) 3-ambas ( )

5.1.3 - Que tipo de árvores?

5.1.4 - Qual a situação dessa mata agora?

por quê?

5.2 -Você participa dos eventos voltado ao meio ambiente realizados dentro do assentamento?.

( )1-sempre ( ) 2-esporadicamente ( ) 3-nunca

Por quê?

5.3- Você participa nos mutirões para o plantio de árvores dentro do assentamento?.

( )1-sempre ( )2-esporadicamente ( ) 3-nunca

Por quê?

5.4 - Quais as alternativas abaixo corresponde com o que você pensa sobre produção agrícola que leva em conta o meio ambiente.

( )1-sonhos da cabeça dos pesquisadores, pois a união dos dois é inviável para a sobrevivência do pequeno produtor

( ) 2-A união dos dois é possível desde que o pequeno produtor receba apoio do governo, 
instituições, etc

( ) 3-É importante respeitar a natureza pois é dela que tiramos nosso sustento

( )4-É impossível; para produzir precisa de espaço e mato, árvores e outros ocupam esse espaço.

5.5- Quando tem que desmatar uma área, você?

( )1-sente pena mas, precisa utilizar a área;

( ) 2-não sente pena pois, precisa utilizar a área;

( ) 3-desmata somente o necessário deixando um pouco da mata;

( )4-nunca desmata

( ) 5-nenhuma das alternativas.

5.6- Você acha que vale a pena implantar sistemas agro-florestais na sua área de plantio?

( ) $1-\operatorname{sim}$ ( )2- não por quê?

5.7- Você acha importante a implantação do turismo rural no assentamento?

( ) 1-sim ( )2- não

Se sim, por quê? (ordem de prioridade)

5.8- Quais as vantagens e desvantagens de utilizar produtos químicos na lavoura? Vantagens:

$\overline{\text { Desvantagens }}$

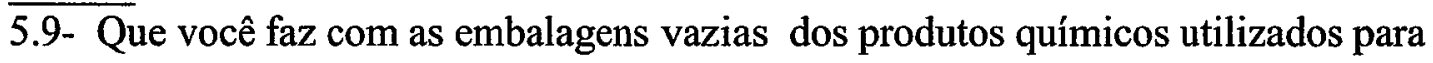
produção?

6- Associação:

6.1- Participa?

( )sim, há

( ) não, Por quê anos

6.2- Papel dentro da associação: 
6.3- Quais atividades a associação promove, qual (is) você acha mais importante ?

6.4 - Você participa de outras atividades extra-associação ( pastoral)?

( ) Sim, Especificar

( ) não

7- Quais os principais problemas da comunidade?

1- Sociais

2- Econômicos

3- Técnicos

4-Ambientais 

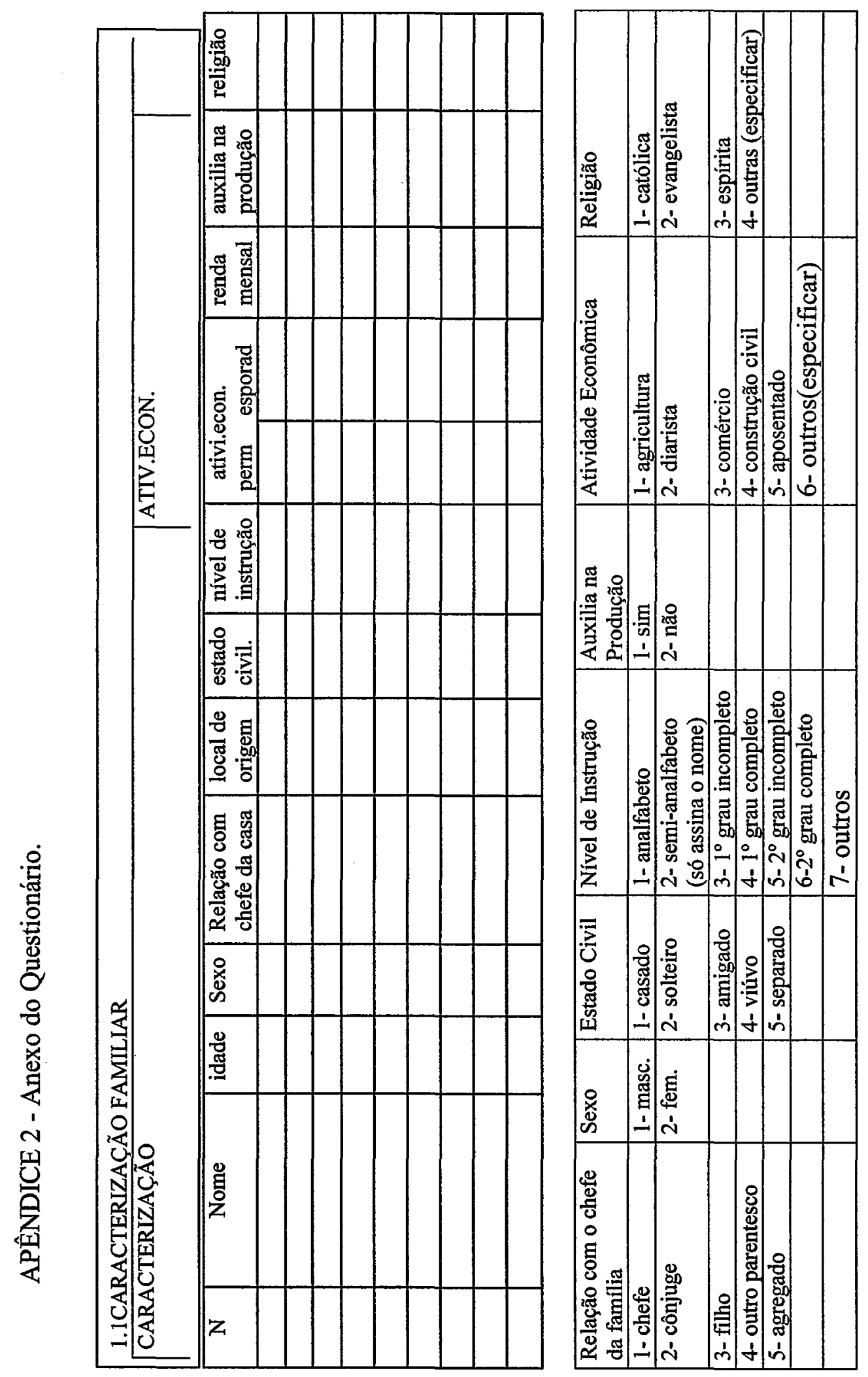

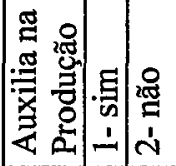

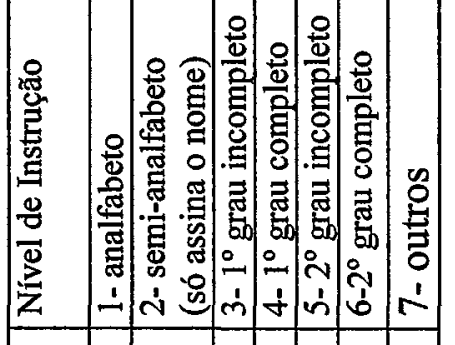

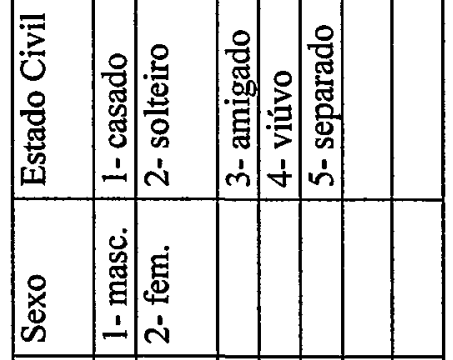

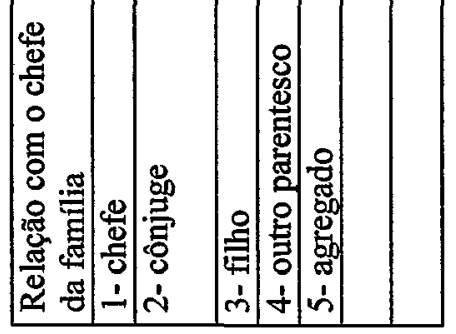


APÊNDICE 3 - Perguntas para verificar a representação ecológica do produtor familiar.

Escala de notas: de $-5 \mathrm{a}+5$.

Pergunta 1 - Você participa dos eventos voltado ao meio ambiente realizados dentro do assentamento?

\begin{tabular}{|l|l|}
\hline Alternativas & Notas \\
\hline 1-sempre & \\
\hline 2-esporadicamente & \\
\hline 3-nunca & \\
\hline
\end{tabular}

Pergunta 2- Por quê você participa ou não participa dos eventos voltados ao meio ambiente realizados dentro do assentamento?

\begin{tabular}{|l|l|}
\hline Alternativas & Notas \\
\hline 1- preocupação ambiental & \\
\hline 2- ajudar o grupo. & \\
\hline 3- mais conhecimento & \\
\hline 4- questão de consciência pessoal & \\
\hline 5- conscientizar outras pessoas & \\
\hline 6- quando tem interesse pessoal & \\
\hline 7- incentivo & \\
\hline 8- Falta de tempo & \\
\hline 9- Saúde & \\
\hline
\end{tabular}

Pergunta 3- Você participa dos mutirões para o plantio de árvores dentro do assentamento?

\begin{tabular}{|l|l|}
\hline Alternativas & Notas \\
\hline 1-sempre & \\
\hline 2-esporadicamente & \\
\hline 3-nunca & \\
\hline
\end{tabular}

Pergunta 4- Porquê você participa (ou não) dos mutirões para o plantio de árvores dentro do assentamento?

\begin{tabular}{|l|l|}
\hline Alternativas & Notas \\
\hline 1. preocupação com o meio ambiente & \\
\hline 2. auxiliar a comunidade & \\
\hline 3. melhorar apresentação do assentamento & \\
\hline 4. responsabilidade dos moradores & \\
\hline 5. gosta de plantar árvore & \\
\hline 6. qualidade de vida & \\
\hline 6. não respondeu & \\
\hline 7. falta de tempo & \\
\hline
\end{tabular}


Pergunta 5- O que você pensa sobre produção agrícola que leva em conta o meio ambiente?

\begin{tabular}{|l|l|}
\hline Alternativas & Notas \\
\hline $\begin{array}{l}\text { 1. sonhos da cabeça dos pesquisadores, pois a união dos dois é } \\
\text { inviável para a sobrevivência do pequeno produtor. }\end{array}$ & \\
\hline $\begin{array}{l}\text { 2. A união dos dois é possível, desde que o pequeno produtor } \\
\text { receba apoio do governo, instituições, etc. }\end{array}$ & \\
\hline $\begin{array}{l}\text { 3. É importante respeitar a natureza, pois é dela que tiramos } \\
\text { nosso sustento. }\end{array}$ & \\
\hline $\begin{array}{l}\text { 4. É impossível: para produzir precisa de espaço. Mato, árvores } \\
\text { e outros ocupam esse espaço. }\end{array}$ & \\
\hline
\end{tabular}

Pergunta 6- Quais os motivos que levaria (ou levou) você a trabalhar com agricultura orgânica?

\begin{tabular}{|l|l|}
\hline Alternativas & Notas \\
\hline 1. Um novo mercado consumidor. & \\
\hline 2. Gastos obtidos para a produção. & \\
\hline 3. Preocupação com o meio ambiente. & \\
\hline 4. Preocupação com a saúde do consumidor. & \\
\hline 5. Preocupação com a saúde do produtor. & \\
\hline 6. Orientação técnica. & \\
\hline 7. Melhor preço. & \\
\hline 8. Não conhece & \\
\hline
\end{tabular}

Pergunta 7- Quando tem que desmatar uma área, você:

\begin{tabular}{|l|l|}
\hline Alternativas & Notas \\
\hline 1. Sente pena, mas precisa utilizar a área. & \\
\hline 2. Não sente pena porque precisa utilizar a área. & \\
\hline 3. Desmata somente o necessário deixando um pouco da mata & \\
\hline 4. Nunca desmata & \\
\hline
\end{tabular}

Pergunta 8- Você acha que vale a pena implantar sistemas agro-florestais na sua área de plantio?

\begin{tabular}{|l|l|}
\hline Alternativas & Notas \\
\hline Sim & \\
\hline Não & \\
\hline
\end{tabular}

Pergunta 9- Porque você acha que vale a pena implantar sistemas agro-florestais na sua área de plantio?

\begin{tabular}{|l|l|}
\hline Alternativas & Notas \\
\hline 1. Outra forma de agricultura que preserva o meio ambiente. & \\
\hline 2. É uma produção sustentável. & \\
\hline
\end{tabular}




\begin{tabular}{|l|l|}
\hline 3. Area pequena suficiente apenas para produzir. & \\
\hline 4. Retorno às origens & \\
\hline 5. Onde há dificuldade de mecanização possibilita o saf. & \\
\hline 6. Desde que refloreste somente com árvores frutiferas & \\
\hline
\end{tabular}

Pergunta 10 - Quais as vantagens de utilizar produtos químicos na lavoura?

\begin{tabular}{|l|l|}
\hline Alternativas & Notas \\
\hline 1. não tem & \\
\hline 2. combate a praga & \\
\hline 3. maior produção & \\
\hline 4. melhora apresentação dos produtos- & \\
\hline 5. única solução & \\
\hline 6. fácil manuseio & \\
\hline
\end{tabular}

Pergunta 11- Quais as desvantagens de utilizar produtos químicos na lavoura:

\begin{tabular}{|l|l|}
\hline Alternativas & Notas \\
\hline $\begin{array}{l}\text { 1. Prejudica a saúde do produtor, do } \\
\text { consumidor e dos animais }\end{array}$ & \\
\hline 2. prejudica o meio ambiente. & \\
\hline 3. contaminação da produção & \\
\hline 4. Aumenta a praga. & \\
\hline 5. gastos com a produção. & \\
\hline 6. cria dependência na produção. & \\
\hline 7. muitas desvantagens & \\
\hline
\end{tabular}

Pergunta 12- Que você faz com as embalagens vazias dos produtos químicos utilizados para produção?

\begin{tabular}{|l|l|}
\hline Alternativas & Notas \\
\hline 1. destinaçăo adequada (revendedor, fabricante, depósito municipal). & \\
\hline 2. deixa empilhado, guardado na roça ou em casa. & \\
\hline 3. Joga no lixo & \\
\hline 4. Utiliza & \\
\hline 5. queima & \\
\hline 6. Enterra & \\
\hline
\end{tabular}


APÊNDICE 4 - Notas dos juízes utilizadas para a construção do IREc.

\begin{tabular}{|c|c|c|c|c|c|}
\hline \multirow[t]{2}{*}{ QUESTÃO ITEM } & \multicolumn{5}{|c|}{ JUIZES } \\
\hline & JUIZ 1 & JUIZ 2 & & JUIZ 4 & JUIZ 5 \\
\hline \multirow[t]{3}{*}{1} & 5 & 3 & 5 & 5 & 5 \\
\hline & 4 & 2 & 2 & 0 & \\
\hline & 1 & -2 & -5 & -5 & -3 \\
\hline \multirow[t]{9}{*}{2} & 5 & 5 & 5 & 5 & 5 \\
\hline & 5 & 3 & 3 & 3 & 3 \\
\hline & 5 & 4 & 4 & 5 & 3 \\
\hline & 5 & 3 & 5 & 5 & 5 \\
\hline & 5 & 2 & 2 & 5 & 4 \\
\hline & 3 & 1 & 1 & 3 & 3 \\
\hline & 5 & 3 & 3 & 0 & 2 \\
\hline & 3 & -1 & 5 & -3 & 2 \\
\hline & 0 & 5 & 5 & 0 & 2 \\
\hline \multirow[t]{3}{*}{3} & 5 & 5 & 5 & 5 & 5 \\
\hline & 3 & 3 & 3 & 0 & 3 \\
\hline & 1 & -3 & -3 & -5 & 0 \\
\hline \multirow[t]{8}{*}{4} & 5 & 5 & 5 & 5 & 5 \\
\hline & 5 & 4 & 5 & 3 & 5 \\
\hline & 4 & 4 & 3 & 3 & 3 \\
\hline & 3 & 5 & 5 & 5 & 3 \\
\hline & 4 & 3 & 3 & 4 & 3 \\
\hline & 5 & 5 & 5 & 3 & 3 \\
\hline & 0 & 0 & 0 & 0 & 0 \\
\hline & 1 & -1 & -1 & -3 & 0 \\
\hline \multirow[t]{4}{*}{5} & -1 & -5 & -5 & -4 & $\overline{0}$ \\
\hline & 3 & 5 & 3 & 3 & 2 \\
\hline & 5 & 5 & 5 & 5 & 3 \\
\hline & -1 & -4 & -4 & -5 & -1 \\
\hline \multirow[t]{8}{*}{$\overline{6}$} & SN & 2 & 3 & 3 & 3 \\
\hline & SN & 2 & 2 & 0 & 2 \\
\hline & SN & 5 & 5 & 5 & 3 \\
\hline & SN & 5 & 5 & 4 & 5 \\
\hline & SN & 5 & 5 & 4 & 3 \\
\hline & SN & 3 & 3 & 3 & 3 \\
\hline & SN & 2 & 3 & 0 & 2 \\
\hline & SN & 0 & 5 & -3 & * \\
\hline \multirow{4}{*}{7} & 4 & 5 & 5 & 3 & 3 \\
\hline & 2 & -5 & 0 & -5 & 2 \\
\hline & 5 & 5 & 5 & 3 & 4 \\
\hline & 0 & 5 & 5 & 5 & 5 \\
\hline \multirow[t]{2}{*}{8} & 3 & 3 & 3 & 5 & 4 \\
\hline & 1 & -3 & -3 & -5 & 2 \\
\hline \multirow[t]{6}{*}{9} & 5 & 5 & 5 & 5 & 3 \\
\hline & 5 & 5 & 5 & 5 & 3 \\
\hline & 4 & 3 & 3 & -3 & 3 \\
\hline & 5 & 3 & 3 & 3 & 0 \\
\hline & 4 & -2 & 3 & 3 & 3 \\
\hline & 3 & -3 & 0 & 0 & ? \\
\hline \multirow[t]{6}{*}{10} & 3 & 5 & 5 & 5 & 3 \\
\hline & 3 & -4 & -4 & 0 & 3 \\
\hline & 5 & -5 & -4 & 0 & 3 \\
\hline & 5 & -5 & -5 & 0 & 1 \\
\hline & -2 & -5 & -5 & 0 & 3 \\
\hline & 1 & -4 & -4 & 0 & 3 \\
\hline
\end{tabular}


APÊNDICE 4 - Notas dos juízes utilizadas para a construção do IREc.

\begin{tabular}{|c|c|c|c|c|c|c|}
\hline \multicolumn{2}{|c|}{ QUESTÃO ITEM } & \multicolumn{4}{|c|}{ JUIZES } & \multirow[b]{2}{*}{ JUIZ 5} \\
\hline & & JUIZ 1 & JUIZ 2 & JUIZ 3 & JUIZ 4 & \\
\hline & & 1 & 2 & 3 & 4 & 5 \\
\hline 11 & 1 & 5 & 5 & 5 & 3 & 4 \\
\hline & 2 & 5 & 5 & 5 & 5 & 4 \\
\hline & 3 & 3 & 5 & 5 & 3 & 4 \\
\hline & 4 & 3 & 5 & 5 & 5 & 3 \\
\hline & 5 & 4 & 5 & 5 & 0 & 3 \\
\hline & 6 & 5 & 5 & 5 & 3 & 3 \\
\hline & 7 & 4 & 5 & 5 & 0 & 4 \\
\hline 12 & 1 & 5 & 5 & 5 & 5 & 5 \\
\hline & 2 & -1 & -5 & -5 & 3 & 2 \\
\hline & 3 & 2 & -5 & -5 & -3 & 3 \\
\hline & 4 & -2 & -5 & -5 & -5 & 2 \\
\hline & 5 & -3 & 3 & 3 & 0 & 3 \\
\hline & 6 & -2 & 0 & 0 & -3 & 3 \\
\hline
\end{tabular}

